\title{
15. PLANKTONIC FORAMINIFERAL BIOSTRATIGRAPHY OF THE PALEOGENE OF SITES 360 TO 364 AND THE NEOGENE OF SITES 362A, 363, AND 364 LEG 40
}

\author{
Monique Toumarkine, Geology Department, Swiss Federal Institute of Technology, Zurich, Switzerland
}

\section{INTRODUCTION}

This paper describes the Paleogene planktonic foraminifer faunas of Holes 360 to 364 , and those of the Neogene of Holes 362A, 363, and 364. The Neogene recovery of Hole $362 \mathrm{~A}$ is confined to Core 1, the corecatcher sample being of lower Miocene (Globigerinoides primordius Zone) age. From Hole 363 only Core 1 and the uppermost part of Core 2 fall into the Neogene. The five uppermost Cores of Site 364 range from Pleistocene to middle Miocene. The planktonic foraminifera of the more extended and closely cored Neogene sections of Sites 360 and 362 are described by Jenkins, this volume. Paleogene sediments were recovered in Holes 360, 361 (Cape Basin), 362A, 363 (Walvis Ridge), and 364 (Angola Basin). A considerable faunal difference exists between the colder water sequences in the Cape Basin and those of the tropical Angola Basin. The southern most faunas of Holes 360 and 361 are a mixture of cool and temperate water species, which are difficult to fit into a clear-cut zonation. The usual tropical and temperate zonations of the tropical North Atlantic, the Caribbean, and the Mediterranean areas (Bolli, 1966; Saunders et al., 1973; Toumarkine and Bolli, 1975) can, however, be applied to the Walvis Ridge Sites 362 and 363 and the Angola Basin Site 364. The difficulty of assigning zones is accentuated at Sites 360 and 361 by strong dissolution effects, which also prevent zonal assignment over broad intervals of the section at Site 364. Dissolution effects also occur, though to a lesser degree, at the other sites. These effects, with their adverse influence on zonation and on environmental interpretation are described in a separate section of this report. A detailed study of the Globigerinatheka group was done, showing the stratigraphic and ecologic significance of the genus and its species at Sites 360 and 363. A general comparison between the faunas at Leg 40 sites, and the faunas of other areas such as the Caribbean and Mediterranean, suggests that in the Leg 40 area certain taxa have somewhat different stratigraphic ranges, resulting probably from ecological influences.

Illustrated specimens are deposited at the Museum of Natural History Basel, under the numbers C-33616 to C-33766.

\section{DISTRIBUTION OF THE PLANKTONIC FORAMINIFERS}

\section{Hole 360}

Site 360 (lat $35^{\circ} 51^{\prime} \mathrm{S}$, long $18^{\circ} 05^{\prime} \mathrm{E}$, water depth 2949 $\mathrm{m}$ ) is located midway down the continental rise of

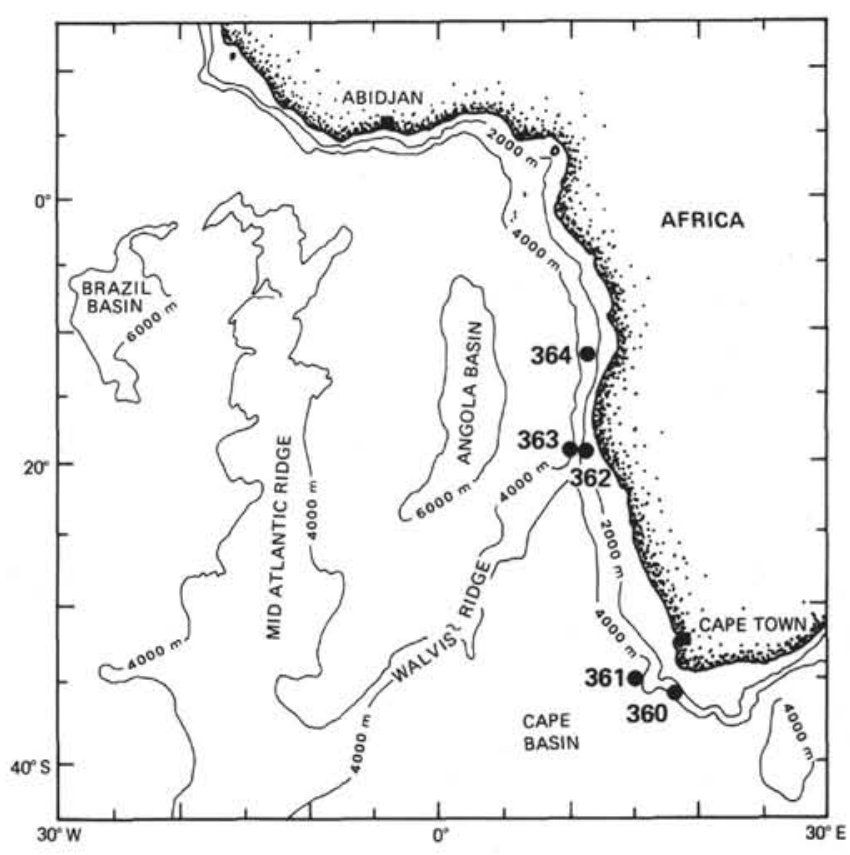

Figure 1. Location of Holes 360, 361 362, 363364 of Leg 40.

southwest Africa. The Paleogene microfauna of Site 360 reflects a strong influence of cool water masses. It is poor in species and the Globorotalia are without peripheral keels. It is likely, however, that carbonate dissolution effects could also, at least to some degree, be responsible for the impoverished fauna. Some samples only contain three or four species. suggesting that the more delicately built species, in particular, have been destroyed through selective dissolution (Cita, 1970; Premoli Silva and Bolli, 1973).

It is difficult to apply the tropical zonal scheme (Bolli, 1966; Saunders et al., 1973) to the Eocene part of the section. However, the middle/upper Eocene boundary (placed above Sample 42-2,58-60 cm) can be established on the basis of the extinction of spinose species, mostly Globorotalia bullbrooki and Globorotalia spinuloinflata. The middle Eocene planktonics are principally represented by various Globigerina, numerous Globigerinatheka, few Hantkenina, and compact Globorotalia. The upper Eocene (Samples 41, $\mathrm{CC}$ to $35-3,11-14 \mathrm{~cm}$ ) contains a rather undiversified fauna with Globigerina, Globigerinatheka, and very rare Hantkenina and Globorotalia cerroazulensis pomeroli. In contrast to the Eocene, the Oligocene part of the section (Cores $35-2,134-136 \mathrm{~cm}$ to $27-1,58-60 \mathrm{~cm}$ ) can at least in part be dated by means of the tropical zonal 


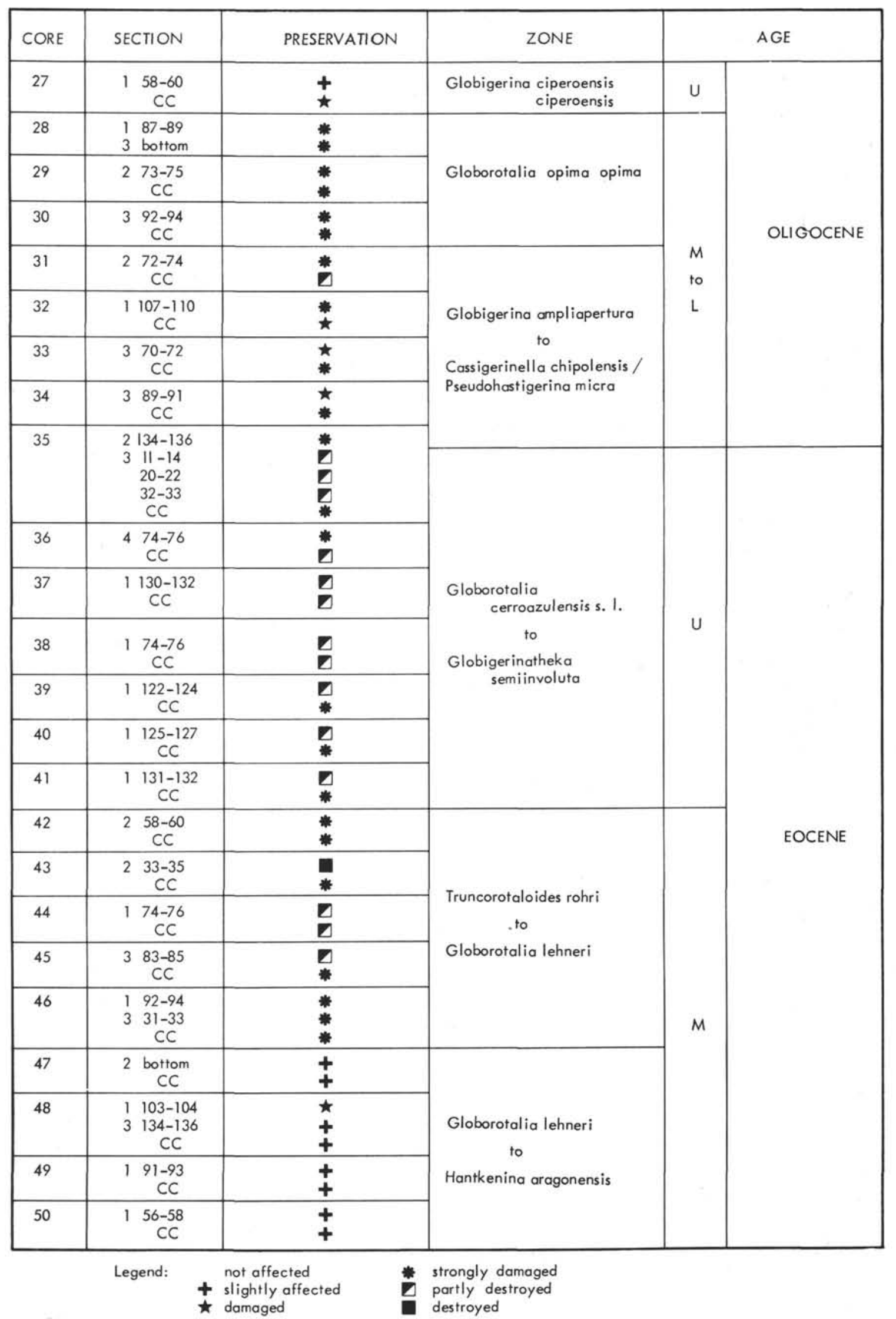

Figure 2. Site 360: Preservation of planktonic foraminifers. 
scheme. This is because the marker species here are more robust, offering higher resistance to dissolution. While the Cassigerinella chipolensis/Pseudohastigerina micra Zone cannot be distinguished from the Globigerina ampliapertura Zone (Samples 35-2, 134-136 cm to $31-2,72-74 \mathrm{~cm}$ ), the Globorotalia opima opima (Samples 30, CC to 28-1, 87-89 $\mathrm{cm}$ ) and Globigerina ciperoensis ciperoensis zones (Samples 27, CC to 27-1, $58-60 \mathrm{~cm})$ are easily recognized. The Sites 360 Paleogene planktonic foraminifers show strong affinities with New Zealand faunas. On the distribution chart for Site 360 (Figure 3) both the New Zealand and the tropical scheme are, therefore, shown.

\section{Hole 361}

Site 361 (lat $35^{\circ} 03^{\prime} \mathrm{S}$, long $15^{\circ} 26^{\prime} \mathrm{E}$, water depth 4549 $\mathrm{m}$ ) is located on the seaward continental rise west of Cape Town. Cores 1-11 contain lower Tertiary planktonic foraminifer faunas. Dissolution effects are so strong here that in several of the examined samples only a very few resistant specimens remain. This is often Globigerina primitiva which, as a result, makes up the major part of the microfauna. Scarcely any keeled Globorotalia are preserved; a dozen or so at the most were seen in all the samples examined and belong in Globorotalia aragonensis and G. spinulosa. In some samples not only the planktonic but also benthic forms have been dissolved. Glauconite and fish debris characterize these residues.

Because of this very fragmentary planktonic foraminifer fauna, it is in most cases not possible to give a zonal assignment, or even a reasonably accurate age determination. The few exceptions are as follows: Samples 11 to $10, \mathrm{CC}$ fall into the Paleocene to lower Eocene: Globorotalia aragonensis caucasica in Sample 7, $\mathrm{CC}$ indicates the uppermost lower Eocene; the faunas of Core 7, Section 1 to Sample 5, CC still contain Globorotalia aragonensis and can therefore be placed within the upper part of the lower Eocene and the lower part of the middle Eocene. Core 4, CC includes only a few specimens of Globigerina primitiva and $G$. senni. The core-catcher sample of Core 1 contains a mixed fauna of the uppermost Eocene (Globigerina tripartita, $G$. venezuelana, $G$. galavisi, $G$. angiporoides, and Globigerinita unicavus) and middle Eocene (Globigerina primitiva, Globigerinatheka $c f$. subconglobata subconglobata, and Globorotalia bullbrooki). It cannot be said whether this heterogeneous association is due to reworking or mixing by drilling.

\section{Hole 362A}

Hole $362 \mathrm{~A}$ (lat $19^{\circ} 45^{\prime} \mathrm{S}$, long. $10^{\circ} 32^{\prime} \mathrm{E}$, water depth $1325 \mathrm{~m}$ ) is located on the Abutment Plateau of the Frio Ridge segment of the Walvis Ridge where the ridge adjoins the continental margin of southwest Africa.

The Paleogene microfauna is frequently poorly preserved and the foraminifers appear broken or rolled. The deepest core, 12 , is referred to the upper part of the lower Eocene and corresponds to the Globorotalia palmerae Zone. The zonal marker is absent but large sized Globorotalia aragonensis caucasica specimens occur. The interval from Core 11 to Sample $8, \mathrm{CC}$ is of middle Eocene age but zonal units are difficult to recognize because some of the index forms are absent.

On the basis of the zonal marker, Sample 8-3, 107$109 \mathrm{~cm}$ is placed in the upper Eocene Globigerinatheka semiinvoluta Zone. The specimens are minute, possess small apertures, and are therefore not very typical. Frequent $G$. subconglobata luterbacheri, and $G$. index index occur together with $G$. semiinvoluta. Sample 6, $\mathrm{CC}$, which contains Hantkenina sp., Cribrohantkenina $\mathrm{sp}$, , and one specimen of Globorotalia cerroazulensis cerroazulensis, belongs in the Globorotalia cerroazulensis s.1. Zone. Persistence of Pseudohastigerina from Sample 6-4, 38-40 cm to Sample 5, CC, together with the absence of Eocene markers, is indicative of the lower Oligocene.

This interval is likely to be of Cassigerinella chipolensis/Pseudohastigerina micra Zone age, but Cassigerinella chipolensis is not present here and appears only within the middle Oligocene. Higher in the section it is possible to recognize the Globigerina ampliapertura Zone (Sample 4, CC to 4-3, 73-75 cm), the Globorotalia opima opima Zone (Samples 3, CC to 3-3, 58-60 cm), and the Globigerina ciperoensis ciperoensis Zone (Samples 2, CC to 2-3, 58-60 cm). Globigerinoides primordius appears above this interval in Sample 1, CC. This together with the extinction of the Globigerina ciperoensis group, indicates the Globigerinoides primordius Zone and the lower limit of the Miocene.

\section{Hole 363}

Hole 363 (lat $19^{\circ} 39^{\prime} \mathrm{S}$, long $09^{\circ} 03^{\prime} \mathrm{E}$, water depth $2248 \mathrm{~m}$ ) is located on the crest of an isolated basement high along the north facing escarpment of the Frio Ridge segment of the Walvis Ridge.

The best Paleogene section of Leg 40 was recovered in this hole. The sequence is nearly complete and has a rich, well preserved planktonic foraminifer fauna, which has very close affinities with the Northern Hemisphere warm to temperate water assemblages as described from Trinidad (Bolli, 1957), and Possagno, Italy (Toumarkine and Bolli, 1975).

The lowermost Paleocene of Samples 18-2,34-38 cm to $18-1,70-72 \mathrm{~cm}$ falls into the Globorotalia pseudobulloides Zone. Above, the Paleocene is well represented with the Globorotalia trinidadensis Zone (Samples 18-1, 52-54 cm to 17, CC), the Globorotalia uncinata Zone (Sample 17-2, 58-60 $\mathrm{cm}$ ), the Globorotalia angulata Zone (Sample 17-1, 87-89 $\mathrm{cm}$ ), the Globorotalia pusilla pusilla Zone (Samples 16, CC to 15, $\mathrm{CC})$, and the Globorotalia pseudomenardii Zone (Samples 15-3, 58-60 cm to 15-1, 58-60 cm). The Globorotalia velascoensis Zone was not found in the samples examined. The next higher sample (Sample 14, CC) is already within the basal lower Eocene Globorotalia edgari Zone. The overlying lower Eocene is assigned to the Globorotalia subbotinae Zone (Samples 14-4, 58-60 $\mathrm{cm}$ to $13, \mathrm{CC}$ ), the Globorotalia formosa formosa Zone (Core 13-4, 58-60 cm), the Globorotalia aragonensis Zone (Sample 13-2, 85-87 cm), and the Globorotalia palmerae Zone (Samples 12,CC to 11, CC). The top of the lower Eocene occurs in Sample 11, CC, which contains beautifully preserved Globorotalia aragon- 


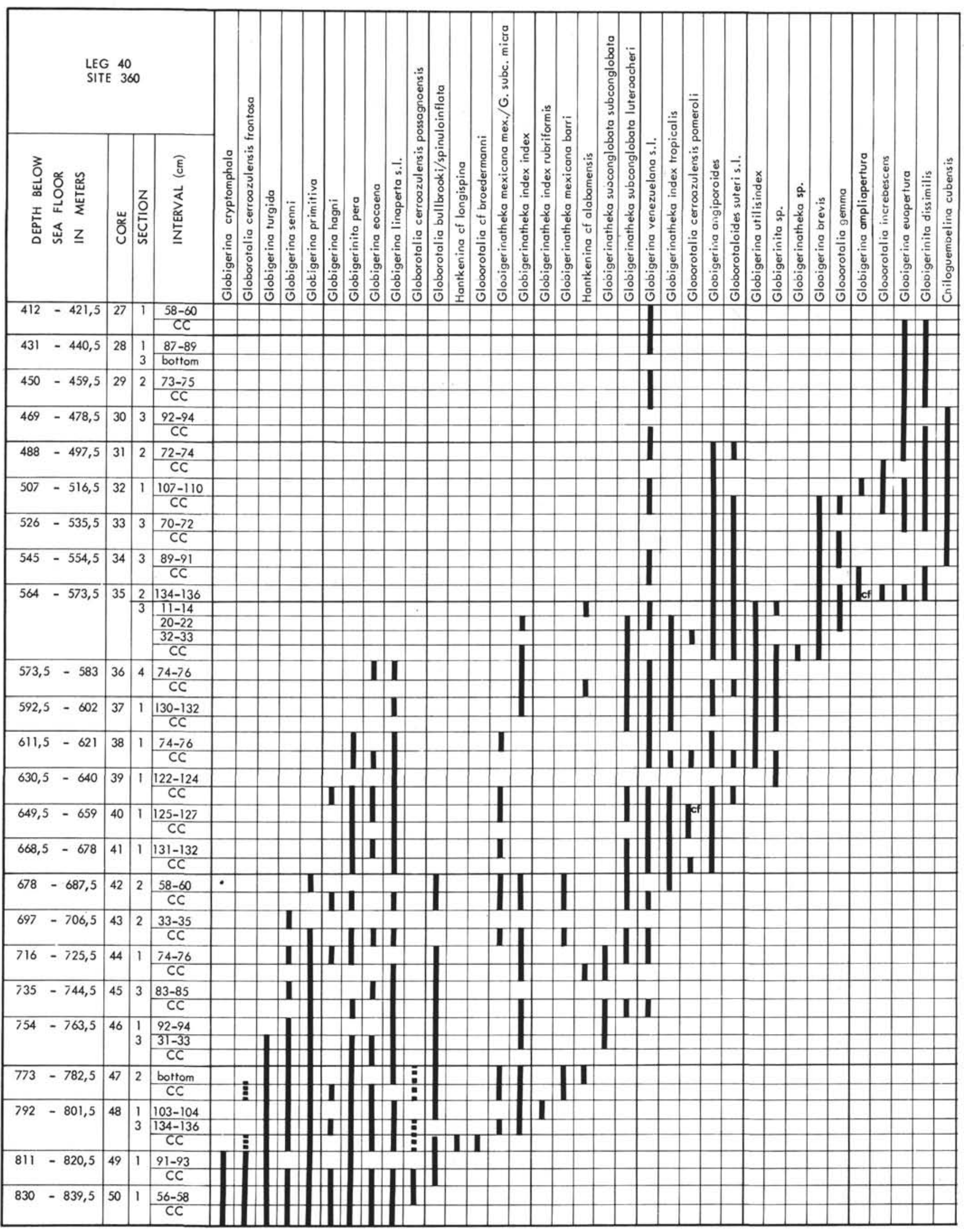

Figure 3. Distribution of middle Eocene and upper Oligocene planktonic foraminifers at Site 360. 


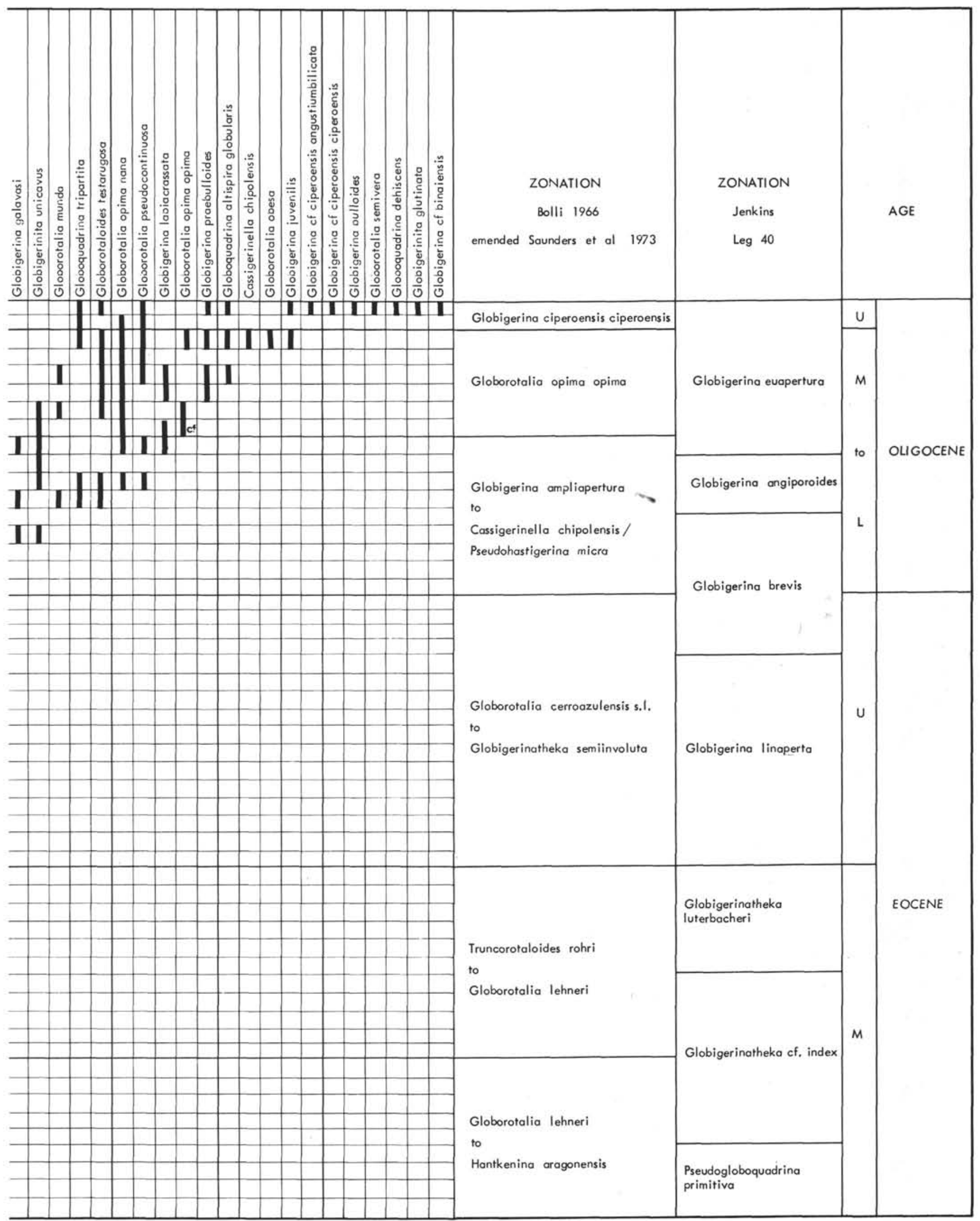

Figure 3. (Continued). 


\begin{tabular}{|c|c|c|c|c|}
\hline CORE & SECTION & PRESERVATION & ZONE & AGE \\
\hline \multirow[t]{2}{*}{1} & \multirow{2}{*}{$\begin{array}{cc}1 & 58-60 \\
3 & 28-30 \\
\text { CC }\end{array}$} & & & \\
\hline & & + & & UPPER EOCENE \\
\hline 2 & $\begin{array}{c}258-60 \\
\text { CC }\end{array}$ & & & \\
\hline 3 & $\begin{array}{c}160-62 \\
C C\end{array}$ & & & \\
\hline \multirow[t]{2}{*}{4} & \multirow{2}{*}{$\begin{array}{c}158-60 \\
\text { CC }\end{array}$} & \multirow{2}{*}{$\square$} & & \\
\hline & & & & \multirow{3}{*}{ MIDDLE EOCENE } \\
\hline 5 & $\begin{array}{c}440-42 \\
\text { CC }\end{array}$ & + & & \\
\hline \multirow[t]{2}{*}{6} & \multirow{2}{*}{$\begin{array}{c}358-60 \\
\text { CC }\end{array}$} & + & \multirow{3}{*}{$\begin{array}{c}\text { Globorotalia palmerae } \\
\text { (equivalent) }\end{array}$} & \\
\hline & & & & \multirow[b]{2}{*}{ LOWER EOCENE } \\
\hline 7 & $\begin{array}{c}110-112 \\
C C\end{array}$ & $\stackrel{+}{+}$ & & \\
\hline 8 & $\begin{array}{c}582-84 \\
\text { CC }\end{array}$ & $\nabla$ & & \multirow{3}{*}{ 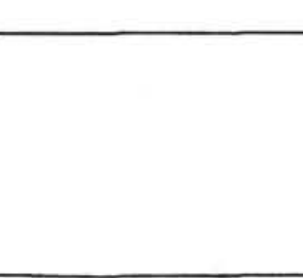 } \\
\hline 9 & $\begin{array}{c}48-60 \\
\text { CC }\end{array}$ & a & & \\
\hline \multirow[t]{2}{*}{10} & \multirow{2}{*}{$\begin{array}{c}458-60 \\
\text { CC }\end{array}$} & \multirow{2}{*}{$\square$} & & \\
\hline & & & & \multirow{2}{*}{$\begin{array}{l}\text { LOWER EOCENE } \\
\text { to } \\
\text { PALEOCENE }\end{array}$} \\
\hline 11 & $\begin{array}{c}458-60 \\
\text { CC }\end{array}$ & 口 & & \\
\hline
\end{tabular}

Figure 4. Site 361: Preservation of planktonic foraminifers.

ensis caucasica. In the middle Eocene, which is reduced and restricted to Samples $11-4,58-60 \mathrm{~cm}$ to $10-4,58-60$ $\mathrm{cm}$, it is possible to approximately distinguish the Globorotalia lehneri (Samples 11-4, 58-60 cm to 11-1, $58-60 \mathrm{~cm}$ ), Orbulinoides beckmanni (Sample 10, CC), and Truncorotaloides rohri (Samples 10-6, $58-60 \mathrm{~cm}$ to $10-4,58-60 \mathrm{~cm}$ ) zones. The genus Globigerinatheka is very well developed here, especially the evolutionary lineage $G$. subconglobata curryi-G. subconglobata euganea-Orbulinoides beckmanni, as is also the $G$. index group and $G$. subconglobata luterbacheri.

Of particular interest is the evolution of the Globorotalia cerroazulensis subspecies during the middle Eocene. Within the Globorotalia lehneri Zone, Globorotalia cerroazulensis frontosa and $G$. cerroazulensis possagnoensis occur in the same way as in the alpine Mediterranean and the Caribbean areas (Toumarkine and Bolli, 1970). In the next younger Orbulinoides beckmanni Zone, Globorotalia cerroazulensis pomeroli and G. cerroazulensis cerroazulensis are present, while some G. cerroazulensis cocoaensis specimens were observed in the highest middle Eocene Truncorotaloides rohri Zone. This is in contrast to other areas studied so far, where Globorotalia cerroazulensis cerroazulensis appears for the first time only in the Truncorotaloides rohri Zone and $G$. cerroazulensis cocoaensis in the upper Eocene.
The upper Eocene, though reduced, is represented in Samples $10-1,58-60 \mathrm{~cm}$ to $9-3,98-100 \mathrm{~cm}$. The Globigerinatheka semiinvoluta Zone (Samples 10-1, 58$60 \mathrm{~cm}$ to $9, \mathrm{CC}$ ) only contains small specimens of the marker. In this zone, Globorotalia cerroazulensis cunialensis appears earlier than usual; some specimens possess a very large and thin last chamber which is, however, often broken. Hantkenina, Cribrohantkenina, and the Globorotalia cerroazulensis group become extinct together at the same level in Sample 9-3, 98-100 $\mathrm{cm}$, at the top of the Globorotalia cerroazulensis s.l. Zone (Samples 9-4, 58-60 $\mathrm{cm}$ to 9-3, 98-100 cm).

Samples $9-3,82-84 \mathrm{~cm}$ to $2-5,58-60 \mathrm{~cm}$ are assigned to the Oligocene. All zones of the tropical zonal scheme can be recognized here on the basis of the presence of the zonal markers. Only Cassigerinella chipolensis appears late, within the Globorotalia opima opima Zone, as is the case also in Hole 362A. The extinction of the genus Pseudohastigerina is therefore used to establish the upper limit of the Cassigerinella chipolensis/Pseudohastigerina micra Zone. Globorotalia opima opima appears early and continues to the top of the Oligocene; i.e., to within the Globorotalia kugleri Zone (Sample 2-5, 58-60 cm). The range of Globigerinoides primordius is also unusual: it appears before Globorotalia kugleri, already in the upper part of the 


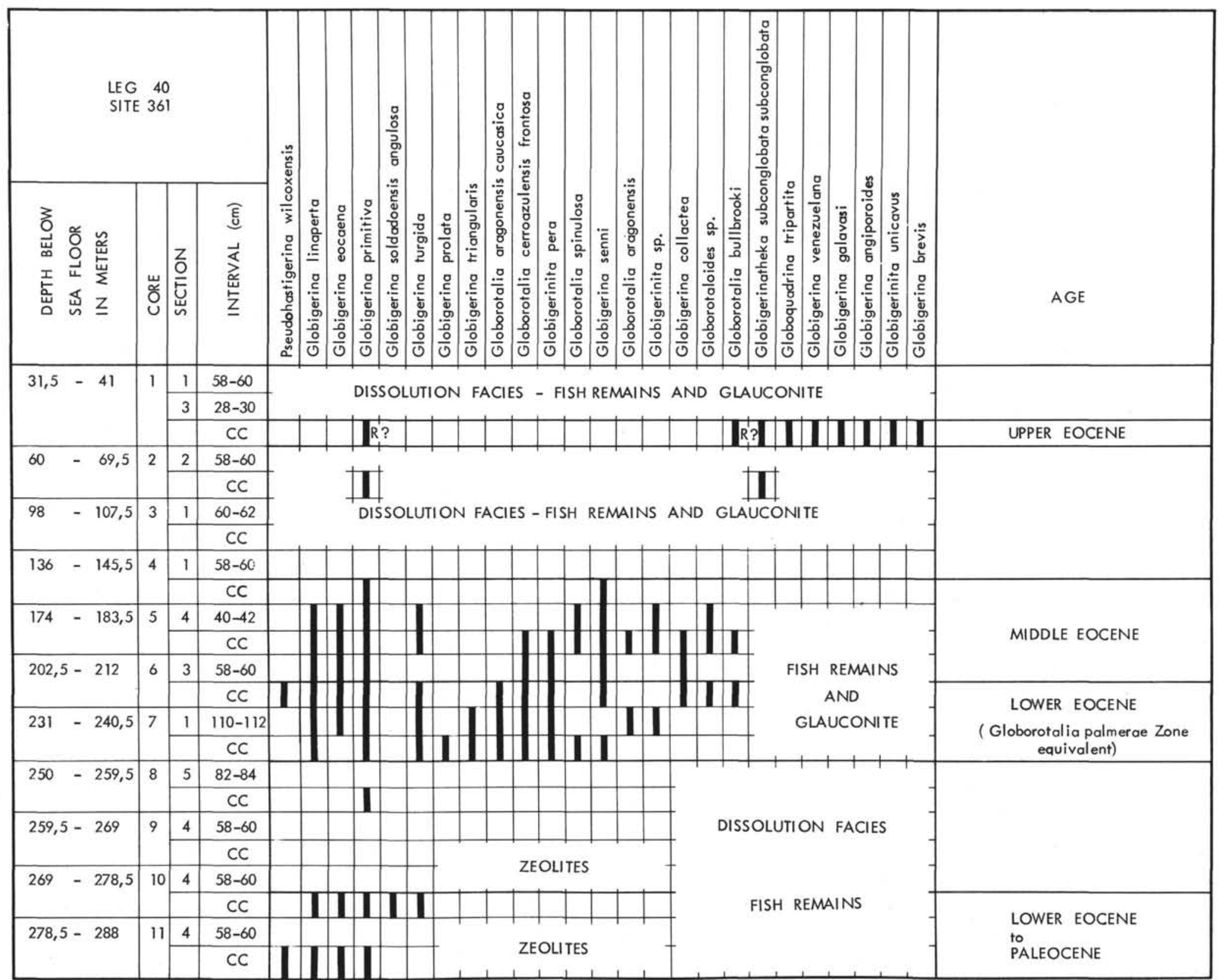




\begin{tabular}{|c|c|c|c|c|c|}
\hline CORE & SECTION & PRESERVATION & ZONE & & AGE \\
\hline 1 & $\mathrm{CC}$ & $\star$ & Globigerinoides primordius & L & MIOCENE \\
\hline 2 & $\begin{array}{c}358-60 \\
\text { CC }\end{array}$ & $\star \star$ & $\begin{array}{r}\text { Globigerina ciperoensis } \\
\text { ciperoensis }\end{array}$ & $U$ & \multirow{5}{*}{ OLIGOCENE } \\
\hline 3 & $\begin{array}{c}358-60 \\
\text { CC }\end{array}$ & * & Globorotalia opima opima & \multirow{2}{*}{ M } & \\
\hline 4 & $\begin{array}{c}373-75 \\
C C\end{array}$ & * & Globigerina ampliapertura & & \\
\hline 5 & $\mathrm{CC}$ & * & \multirow{2}{*}{$\begin{array}{l}\text { Cassigerinella chipolensis / } \\
\text { Pseudohastigerina micra }\end{array}$} & \multirow{2}{*}{ L } & \\
\hline \multirow[t]{2}{*}{6} & \multirow{2}{*}{$\begin{array}{c}438-40 \\
\text { CC }\end{array}$} & \multirow{2}{*}{$\star$} & & & \\
\hline & & & Globorotalia cerroazulensiss.l. & \multirow{3}{*}{ U } & \multirow{9}{*}{ EOCENE } \\
\hline 7 & $\begin{array}{cc}1 & 133-135 \\
3 & 96-97 \\
& C C\end{array}$ & $\begin{array}{l}* \\
+ \\
+\end{array}$ & Globigerinatheka semiinvoluta & & \\
\hline 8 & $\begin{array}{lc}1 & 74-76 \\
3 & 107-109\end{array}$ & & & & \\
\hline & $\mathrm{CC}$ & * & \multirow{3}{*}{$\begin{array}{c}\text { Truncorotaloides rohri } \\
\text { to } \\
\text { Orbulinoides beckmanni }\end{array}$} & \multirow{5}{*}{ M } & \\
\hline 9 & $\begin{array}{c}3113-115 \\
C C\end{array}$ & * & & & \\
\hline \multirow[t]{2}{*}{10} & \multirow{2}{*}{$\begin{array}{cc}1 & 65-67 \\
3 & 130-132 \\
C C\end{array}$} & + & & & \\
\hline & & & \multirow{2}{*}{$\begin{array}{l}\text { Globorotalia lehneri } \\
\text { to } \\
\text { Globigerinatheka } \\
\text { subconglobata subconglobata }\end{array}$} & & \\
\hline 11 & $188-89$ & * & & & \\
\hline 12 & $\begin{array}{l}104-105 \\
108-110 \\
\text { bottom }\end{array}$ & $\begin{array}{l}\text { * } \\
* \\
*\end{array}$ & $\begin{array}{c}\text { Globorotalia palmerae } \\
\text { (equivalent) }\end{array}$ & L & \\
\hline
\end{tabular}

Figure 6. Site 362A: Preservation of planktonic foraminifers.

Globigerina ciperoensis ciperoensis Zone (Sample 2, $\mathrm{CC}$ ). The first appearance of Globigerinoides primordius was originally thought to indicate the lower boundary of the Miocene, but this species has subsequently been recorded on several occasions from older levels (Pujol, 1970; Jenkins, 1973). The nannoplankton, which are of Sphenolithus ciperoensis Zone age, confirm the Oligocene age of Sample 2, CC.

An abrupt faunal change takes place between Sample $1-4,102-104 \mathrm{~cm}$ which still belongs to the Globigerinoides primordius Zone, and Sample 1-4, 75-77 cm, which is of Globorotalia fohsi lobata Zone age. Several zones are obviously missing here. Numerous specimens of Globorotalia fohsi lobata are present among such species as Orbulina suturalis, Sphaeroidinellopsis grimsdalei, and Globorotalia praemenardii. The next higher samples examined, Samples 1-4, 58-60 cm and 12, $58-60 \mathrm{~cm}$, still belong to the Globorotalia fohsi lobata Zone, but show contamination from the Pleistocene. The highest sample taken, Core 1, Section 1-top, at 3140.5 meters below the sea floor is attributed to the
Globorotalia menardii Zone, with Pleistocene contamination.

\section{Hole 364}

Hole 364 lat $11^{\circ} 34^{\prime} \mathrm{S}$, long $11^{\circ} 58^{\prime} \mathrm{E}$, water depth 2448 $\mathrm{m})$ is located in the Angola Basin, some $10 \mathrm{~km}$ landward of an abrupt marginal escarpment that marks the presumed outer limit of a massive layer of salt and evaporites along the continental margin of Southwest Africa.

This site yielded typical, warm-water, PaleogeneNeogene foraminifer faunas strongly affected by dissolution. As a consequence, some intervals are completely devoid of planktonic foraminifers, and in some even the more resistant benthic forms are also largely or totally destroyed. In these intervals the washed residues merely consist of glauconite, zeolites, and fish debris. This is the case especially in Cores 5, 6, and 7 but also more or less characterizes the other intervals where foraminifers are still present. The most 
persistent Eocene planktonic species are Globigerina senni, G. turgida, G. primitiva, and Globorotalia rotundimarginata, all of which possess a thick, pachyform test. Cores 10 to 1 are of Paleocene to Pleistocene age. Because of their wide spacing and the strong dissolution effects described above, only the following zones could be recognized: Globorotalia trinidadensis, Globorotalia angulata, and Globorotalia velascoensis in the Paleocene (Samples 10, CC to 9, CC); and Globorotalia edgari, Globorotalia subbotinae, Globorotalia formosa formosa, and Globorotalia aragonensis in the lower Eocene (Samples 9-3,58-60 cm to 8-4, 58-60 cm). Higher in the section planktonic foraminifer assemblages, consisting mostly of Globigerina, become poor (Samples 8-6, 58-60 $\mathrm{cm}$ and 8-4, 58-60 cm). Finally, only the thick-walled Globigerina senni remains (Sample 7, CC), which is usually the last lower to middle Eocene species to resist dissolution (Premoli Silva and Bolli, 1973). Core 6 is devoid of foraminifers. Sample 5,CC, contains very few planktonic species; it is assigned to the middle Miocene on the basis of the presence of Globorotalia fohsi peripheroronda. Thus, virtually no middle Eocene, no upper Eocene and Oligocene, and almost no lower and middle Miocene were recovered or could be identified at this site.

Sample 4, CC, is of upper Miocene Neogloboquadrina dutertrei Zone age. Samples 3, CC, to 2, CC (very poor) fall into the lower and middle Pliocene Globorotalia margaritae and Globorotalia miocenica zones. Core 1 is Pleistocene, with a rich and well-preserved tropicalsubtropical Globorotalia truncatulinoides truncatulinoides Zone fauna.

\section{The Genus Globigerinatheka}

From observations first made in the Caribbean and Mediterranean regions (Bolli, 1972) and later in the tropical Pacific (Toumarkine, 1975), it became apparent that evolutionary trends within Globigerinatheka and geographic distribution of this group of taxa are of considerable significance for middle and upper Eocene biostratigraphy and paleoecology. Representatives of this genus occur frequently and characteristically in the Eocene of Holes $360,362 \mathrm{~A}$, and 363 . They are here briefly discussed, and their biostratigraphic distribution and paleoecology are compared with those of the above-mentioned regions.

\section{Hole 360}

Two subspecies of this genus are well represented, the dominant and large Globigerinatheka subconglobata luterbacheri and $G$. index index. Also present but not so frequent are $G$. subconglobata subconglobata, $G$. index tropicalis, small forms which belong to $G$. subconglobata micra or $G$. mexicana mexicana, scarce $G$. index rubriformis, and $G$. mexicana barri.

According to Bolli (1972), such an assemblage is typical for a temperate-water fauna. Characteristically tropical forms are absent. Of the temperate water forms, $G$. index index was originally described from New Zealand, G. index rubriformis from the northern Caucasus, and $G$. subconglobata luterbacheri from the Helvetic nappes of central Switzerland. G. mexicana mexicana, G. mexicana barri, and $G$. index tropicalis are regarded as ubiquitous forms, and $G$. subconglobata subconglobata and $G$. subconglobata micra as forms with tendency to a more temperate character.

It is remarkable that Globigerinatheka with the $G$. index group and $G$. subconglobata luterbacheri occurs in Site 360 almost to the top of the upper Eocene. Only the highest Eocene sample investigated (Sample 35-3, 11-14 $\mathrm{cm}$ ) does not contain representatives of this genus. According to previous studies, in high latitudes $G$. index index extends to the top of the Eocene (North Sea Basin, Berggren, 1971; New Zealand, Jenkins, 1971), whereas in low latitudes the subspecies became extinct earlier, within the Globigerinatheka semiinvoluta Zone; $G$. index tropicalis persists slightly above this zone.

The species/subspecies composition of Globigerinathek $a$ and their stratigraphic distribution point to cool to temperate-water conditions for the middle and upper Eocene of Site 360.

\section{Holes $362 \mathrm{~A}$ and 363}

The ranges of the Globigerinatheka species in Holes $362 \mathrm{~A}$ and 363 , are almost identical. The better developed faunas from Site 363 were studied in more detail than those from Hole $362 \mathrm{~A}$.

The Hole 363 Globigerinatheka group is characterized by both cool-temperate forms, such as present in the Cape Basin Site 360, and warm water forms. Well represented here is the stratigraphically significant lineage $G$. subconglobata curryi-G. subconglobata euganea-Orbulinoides beckmanni (Plate 3, Figure 4-13). It was first described by Proto Decima and Bolli (1970) from the Caribbean area (Barbados and Trinidad) and from Northern Italy (Euganean hills).

Some specimens assigned here to the $G$. index group from Samples 10-6, 58-60 cm to $10-1,58-60 \mathrm{~cm}$ differ from the typical forms in that their test shape is more globular (Plate 5, Figures 6-9). Further, they possess only a single, but very large aperture. The sutures on the spiral side are only slightly depressed, while those on the unbilical side are deep. All these features may still be regarded as falling within the variability range of G. index index.

Typical specimens of $G$. index index extend into the upper Eocene of Site 363, together with $G$. index tropicalis. G. subconglobata luterbacheri, as exceedingly large specimens, is also widespread in this section (Samples $10-4,58-60 \mathrm{~cm}$ to $9, \mathrm{CC}$ ). It may be indicative of a persisting temperate water influence. Present in Sample 10-1, 58-60 cm are some specimens of the zonal marker G. semiinvoluta (Plate 5, Figure 10-14). They are very small and not typical and agree best with the north Italian forms described by Toumarkine and Bolli (1975). The same sample also contains other very small specimens, which possess a single but very wide aperture (Plate 5, Figures 15-21). Their general test shape is nearly spherical and close to that of G. semiinvoluta, with the last chamber often larger than the early part of the test and covering the umbilical area. This form will be described in more detail in a subsequent publication.

Site 363 shows both the influence of cold water from the south and tropical water from the north. This probably explains the peculiar variation here in some populations of the genus Globigerinatheka, such as 


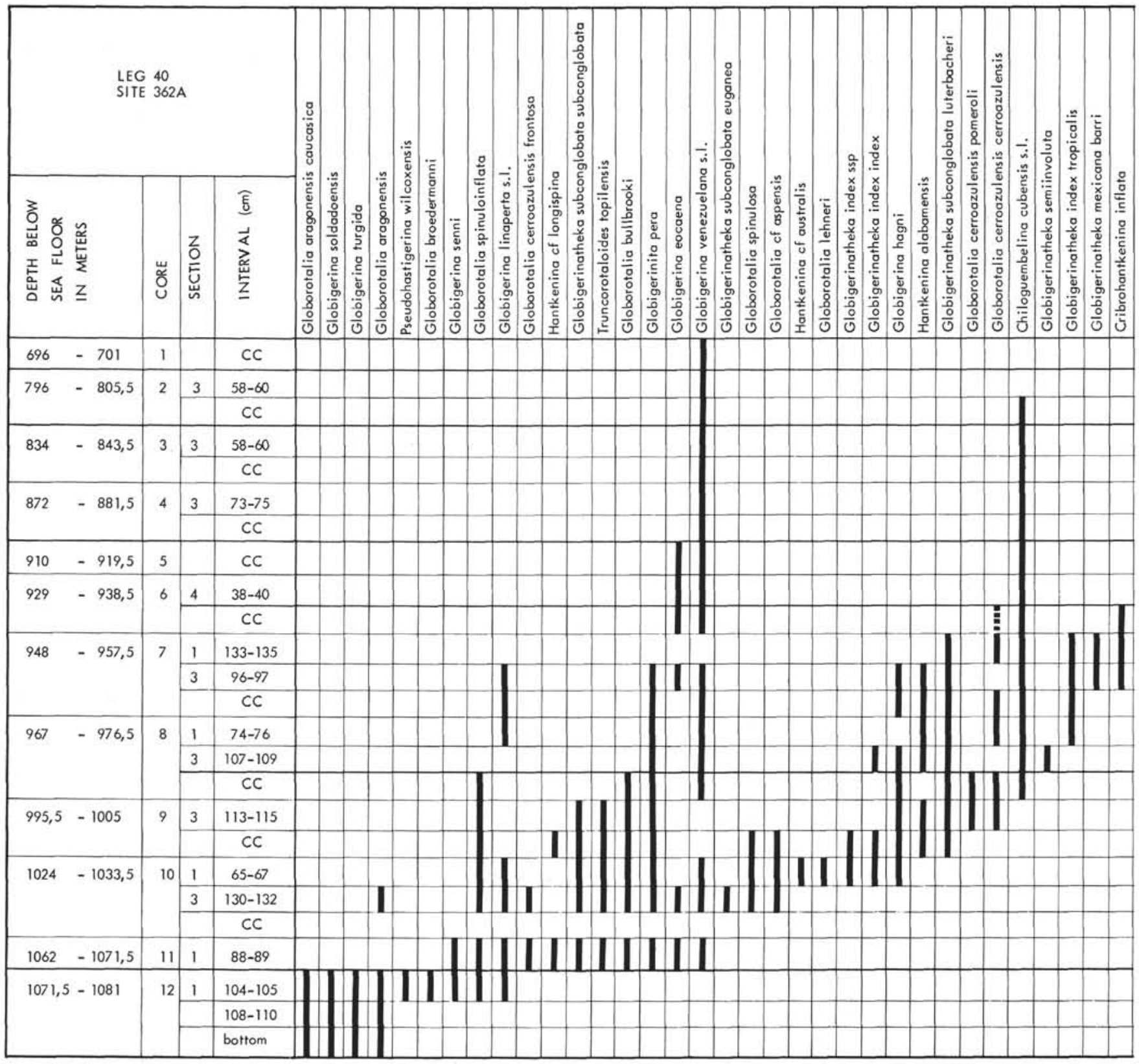

Figure 7. Distribution of lower Eocene to lower Miocene planktonic foraminifers in Hole $362 \mathrm{~A}$.

those of $G$. index or $G$. semiinvoluta, which are likely the result of adaptation to the local ecological conditions.

\section{DISSOLUTION EFFECTS ON PLANKTONIC FORAMINIFERS IN THE PALEOGENE OF LEG 40}

Dissolution effects on foraminifers were previously described and illustrated by Berger (1968, tropical Atlantic; 1970 East Pacific Rise; 1972, DSDP Leg 1 to 7), Berger and von Rad (1972, Leg 14), Cita (1970a, b, Legs 1 to 4), Jenkins and Orr (1972, Leg 9), Premoli Silva and Bolli (1973, Leg 15), and Toumarkine (1975, Leg 32). To a variable extent dissolution has affected the Paleogene foraminifers of Leg 40, in particular those of Sites 360,361 , and 364, where it makes species determinations and recognition of zonal intervals difficult. Because of totally destroyed faunas it was impossible to make zonal assignments for considerable intervals of Sites 361 and 364 .

\section{Holes 360 and 361}

As a result of dissolution effects and species impoverishment due to climate (cold-temperate water) and geographic position (high latitude), the Paleogene planktonic foraminifer assemblages are often strongly damaged and reduced in species diversity. These two factors are regarded as instrumental in the absence of keeled Globorotalia and spinose and thin-walled globigerinid species. The resulting planktonic foraminifer association at Sites 360 and 361 is composed mostly of thick-walled and compact 


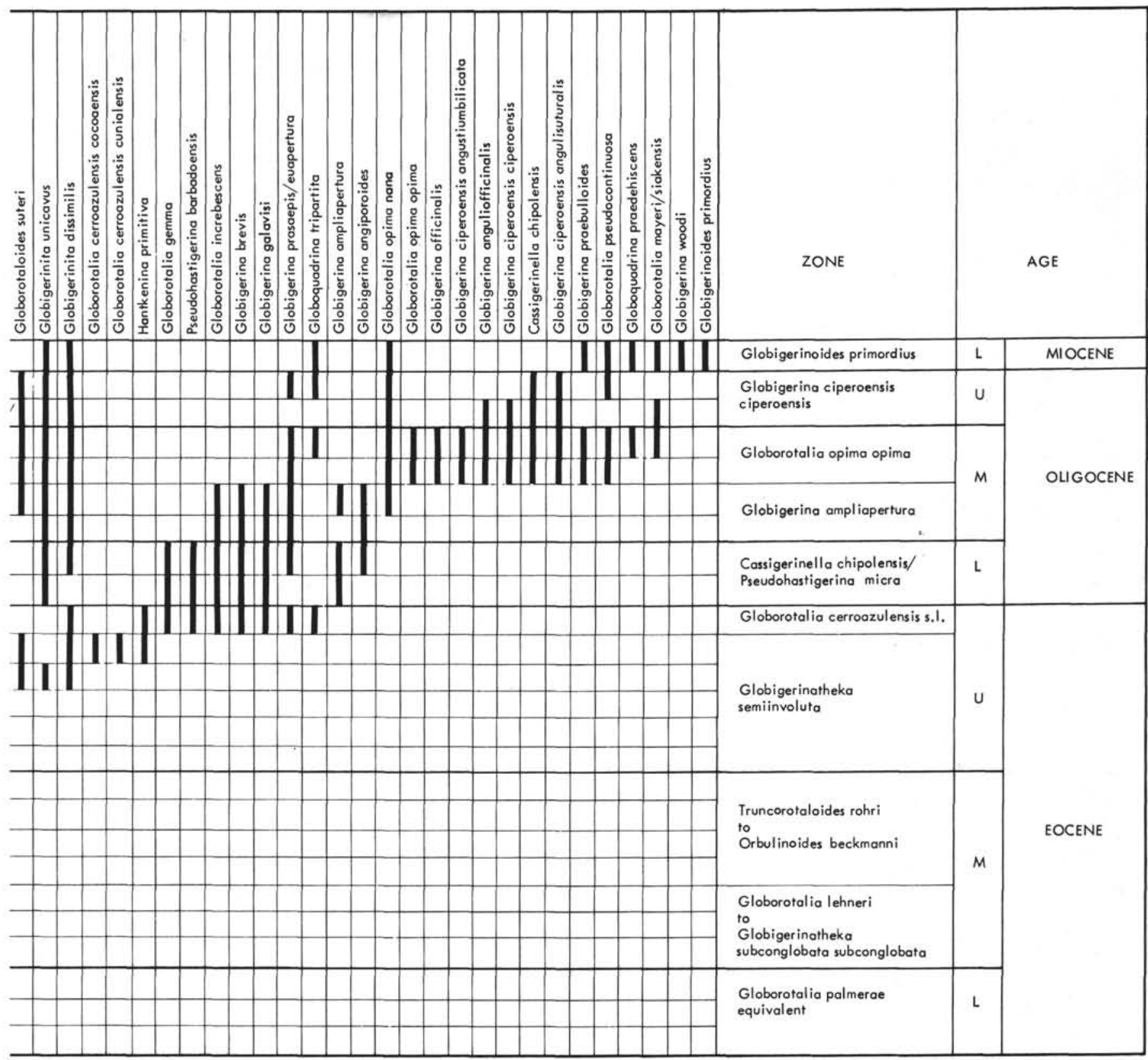

Figure 7. (Continued).

Globigerina species such as G. senni, G. primitiva, and $G$. turgida.

\section{HOLE 360 (FIGURE 2)}

Most of the tests of thick-walled Globigerina, the only forms to survive dissolution, are heavily broken, usually along umbilical sutures. It appears that the thinner and more delicate inner chambers are dissolved prior to breaking up of the test. Such an empty test is shown in Figure 9 of Plate 10. Undamaged specimens are rare among the frequent broken forms. The only observed Paleogene species are Globigerina linaperta, $G$. senni, $G$. primitiva, $G$. eocaena, G. turgida, $G$. venezuelana, $G$. angiporoides, Globorotalia spinuloinflata, and various Globigerinatheka and Globigerinita.
With progressive dissolution, Globigerina senni is the last species to disappear. Test ornamentation such as spines or pustules may produce, when affected by dissolution, a glittering appearance to the surface (Plate 10, Figure 7). Thin-walled specimens may become nearly transparent in the advanced stages of dissolution, and holes may form-a feature not observed in thick-walled specimens. A good example of this is shown by a specimen of Globorotalia opima nana in Figure 15 of Plate 10.

\section{HOLE 361 (FIGURE 4)}

Paleogene faunas are so poor at this site because of dissolution that only exceptionally it is possible to assign a sample to a zone. Several of the examined 


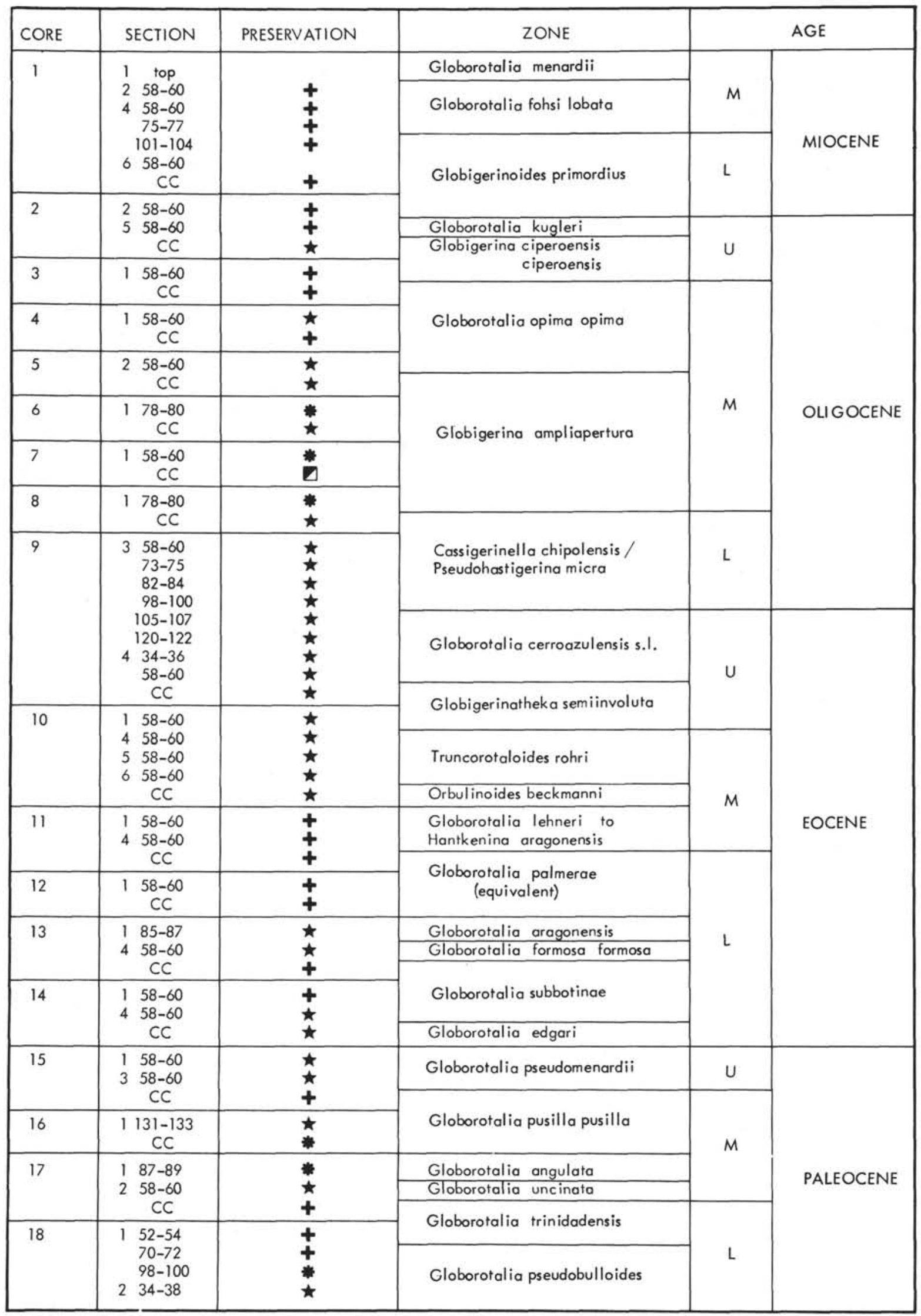

Figure 8. Site 363: Preservation of planktonic foraminifers. 
samples contain fish debris, zeolites, and glauconite only, and are devoid of planktonic foraminifers. Some others (Cores 5 to 7 ) include sparse but well-preserved faunas.

\section{Holes $362 \mathrm{~A}$ and 363 (Figures 6 and 8)}

Dissolution effects on Paleogene assemblages here are not as strong as at Sites 360, 361, and 364 . Nonetheless, many specimens, Globigerina angiporoides for example (Plate 10, Figure 5), show distinct holes in their chamber walls. Such a dissolution pattern is characteristic for the thinner walled species present here, and stands in contrast to thicker walled forms, such as $G$. senni, which, with progressive dissolution, have a tendency to break up instead of first forming holes in the chamber walls. Larger crystals, as they often occur surrounding pores, are more resistant to dissolution. This is clearly shown in the illustrated specimen of Globigerina praesaepis (Plate 11, Figures 24 ), where pores became funnel-shaped through better preservation of the larger crystals.

The external wall layers have a tendency to remain better preserved along the depressed sutures (Globorotalia cerroazulensis pomeroli, Plate 6 , Figures 7,$8 ; G$. cerroazulensis cerroazulensis, Plate 6, Figures 10-12). When the external layers have dissolved the inner one may still be preserved but is then often pierced by holes as in the Globigerina ampliapertura specimen illustrated on Plate 11, Figures 12, 14.

\section{Hole 364 (Figure 10)}

Dissolution effects from the lower Eocene to the upper Miocene (Core 8, Section 1 to Sample 4, CC) are so strong that no zonation on the basis of planktonic foraminifers is possible. Most sediments of this interval contain only fish debris, radiolarians, diatoms, and sponge spicules, but no foraminifers. Only a few samples, such as 8-6, 58-60 $\mathrm{cm}$, include some Globigerina primitiva and $G$. senni, leaving an initial impression that these represent cold-water assemblages. However, on the basis of the zones recognized in the better-preserved parts of the site, which are of typical tropical character, it is probable that warmer water and thinner shelled forms must have existed here but have subsequently become victims of dissolution.

It can clearly be observed in the material from this site that in thick walled specimens dissolution first affects the umbilical area around the aperture, which as a result increses in size (e.g., Globigerina senni, Plate 10 , Figures 10-12). Dissolution then progressively destroys the inner whorls, and as a last phase the remainder of the test breaks up. In thinner walled specimens the mode of progressive destruction is by means of holes being formed in chamber walls, followed by the destruction of the initial spire (Plate 10, Figure 1).

\section{Conclusions}

Dissolution of a foraminiferal population may proceed along different paths, depending on the composition of the assemblage and the construction of the test walls of individual species. The effects of progressive dissolution can be subdivided as follows:
1) Corrosion of tests resulting in enlarged pores, more pronounced spines, enhanced umbilical aperture, all caused by selective dissolution between different sized crystals (Site 363, Sample 5, CC). Holes in thinwalled tests often occur first in the last chamber which is usually thinner than the previous ones. When such tests break up, they rapidly dissolve with few fragments left (Site 360, Sample 30-3, 92-94 cm). At the same time, the inner whorls of thick tests are destroyed, followed by fragmentation of the remaining outer chambers $(364-8-4,58-60 \mathrm{~cm})$.

2) In more strongly affected assemblages, all spinose and thin-walled forms disappear, leaving only thickwalled and compact species. At this stage it is often the index forms that go first, thus making dating of the samples difficult or impossible. Such selective dissolution of species may also lead to difficulties in paleoclimatic interpretation because the forms that are more resistant to dissolution also have a wider latitudinal distribution. This shows, for instance, in a comparison of the faunas from tropical Site 364 in the Angola Basin (Samples 8-4, 58-60 $\mathrm{cm}$ to 8-6, 58-60 cm) with the cold-temperate Site 360 , Sample 46, CC in the Cape Basin.

3) Eventually all planktonic foraminifers are destroyed; only some of the more-resistant benthic foraminifers remain. The relative proportion of solution-resistant fish debris and siliceous forms increases (Site 361, Sample 8-5, 82-84 cm; Site 364, Sample 7, CC).

4) Finally, calcareous forms no longer occur; faunal remains are restricted to fish debris and siliceous fossils such as diatoms, radiolarians, and sponge spicules. A typical example is Core 6 of Site 364 .

\section{REMARKS ON SPECIES DISTRIBUTION AND PALEOGEOGRAPHY}

The Paleocene through Eocene planktonic foraminifer assemblages show no remarkable difference between Sites 363 and 364. The same also goes for the lower Eocene faunas of Holes 362A, 363, and 364. They are similar to those of the tropical (e.g., Caribbean) and Mediterranean areas. It is noteworthy that Globorotalia palmerae, confined to a narrow latitudinal belt in the Northern Hemisphere (Caribbean-Morocco-southern Mediterranean-Pakistan), was not seen at any of the Leg 40 sites. However, Globorotalia aragonensis caucasica, a more temperate species, occurs as wellpreserved specimens at Holes $362 \mathrm{~A}$ and 363.

Middle and upper Eocene sediments were recovered from Holes 360, 362A, and 363. As in the Paleocene and lower Eocene, the planktonic foraminifers of Holes $362 \mathrm{~A}$ and 363 are similar to those of the tropical and Mediterranean areas, with some deviations as noted for the distribution of the Globigerinatheka species and the range of the Globorotalia cerroazulensis group. The faunas of both these sites are very different from that of Site 360 , which is extremely poor. Together with the cool-water environment, causing the scarcity of some species such as keeled Globorotalia and Hantkenina, selective dissolution has played a dominant role at this 


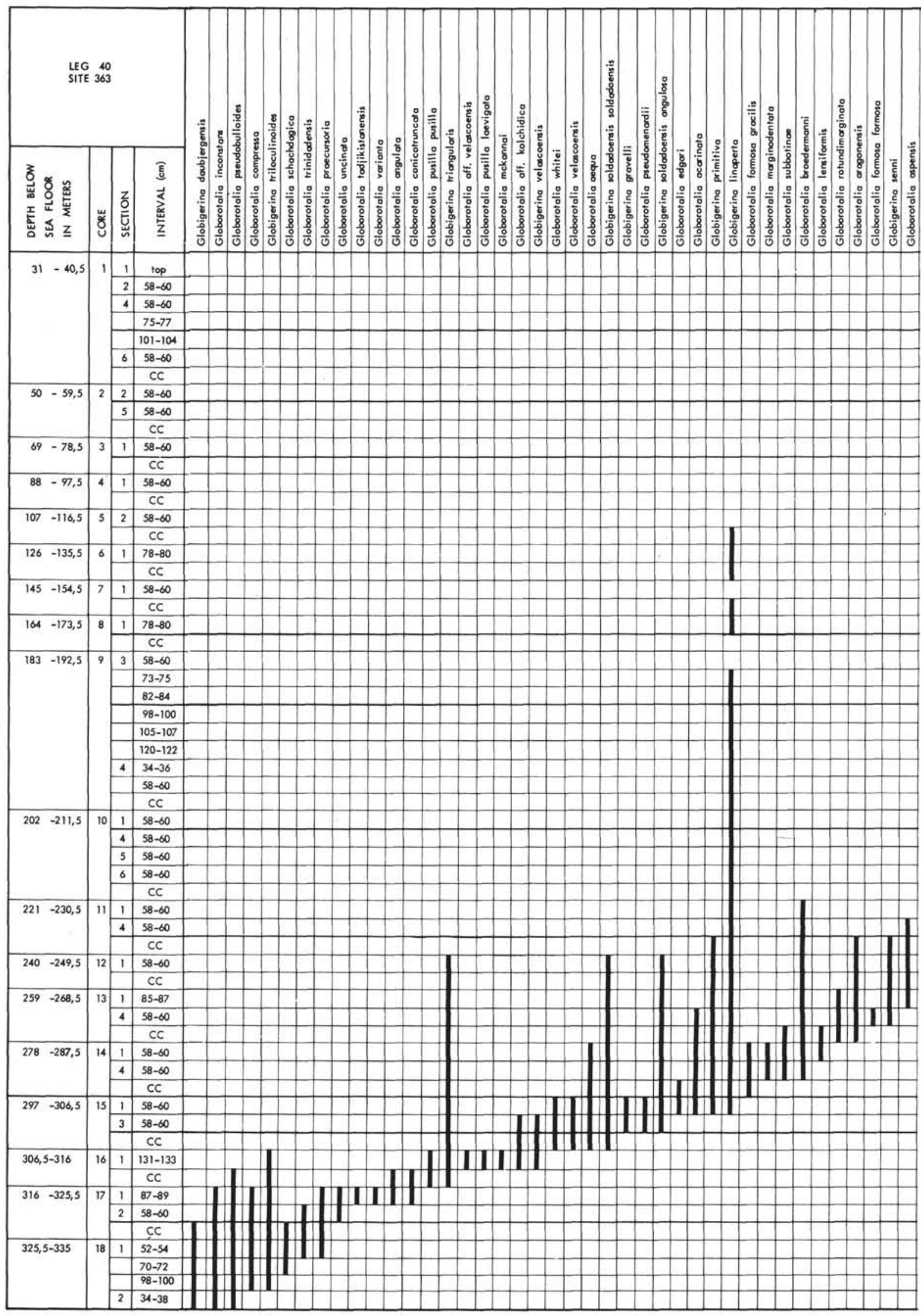

Figure 9a. Distribution of lower Paleocene to middle Miocene planktonic foraminifers at Site 363. 


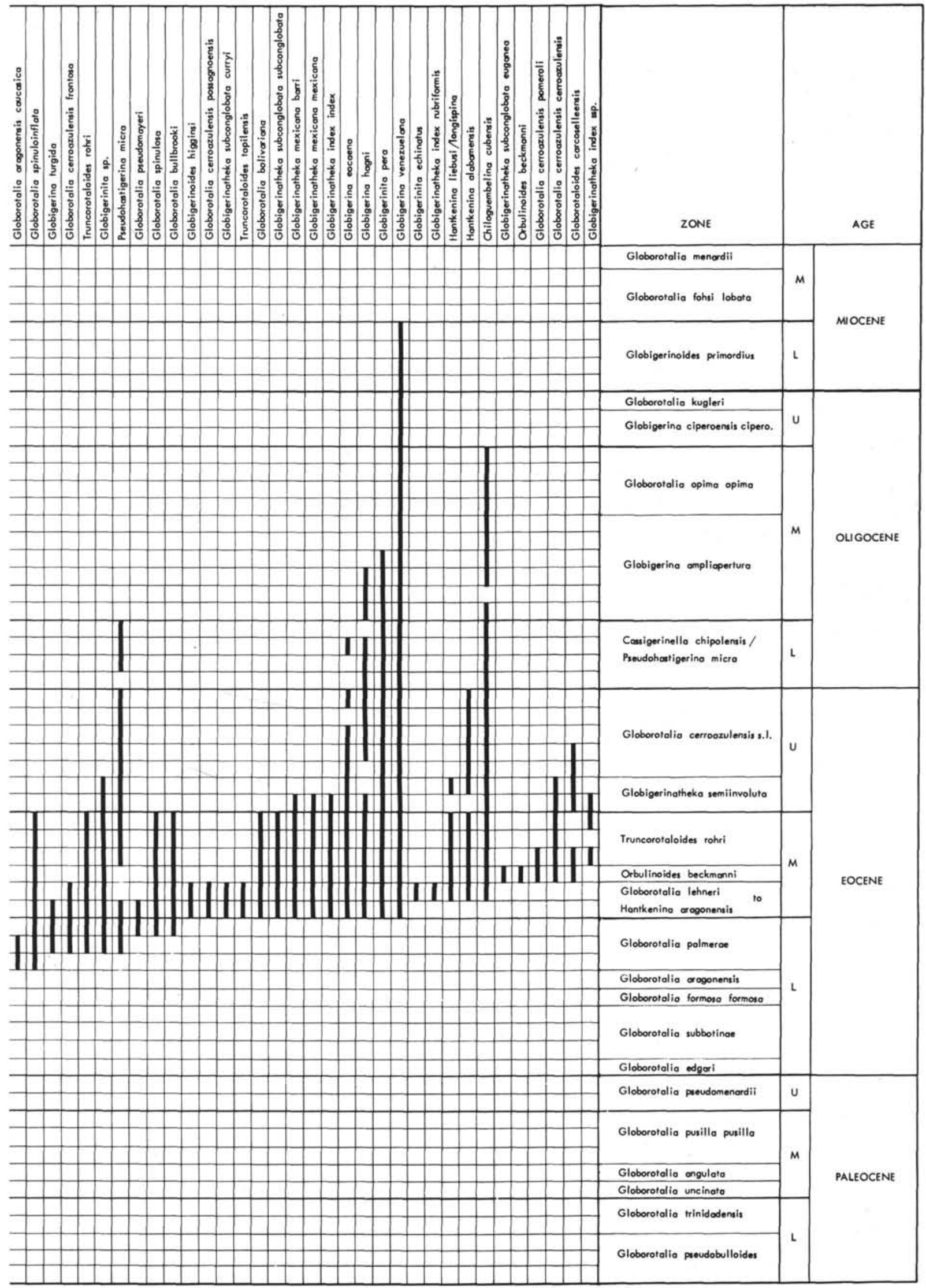

Figure 9a. (Continued). 


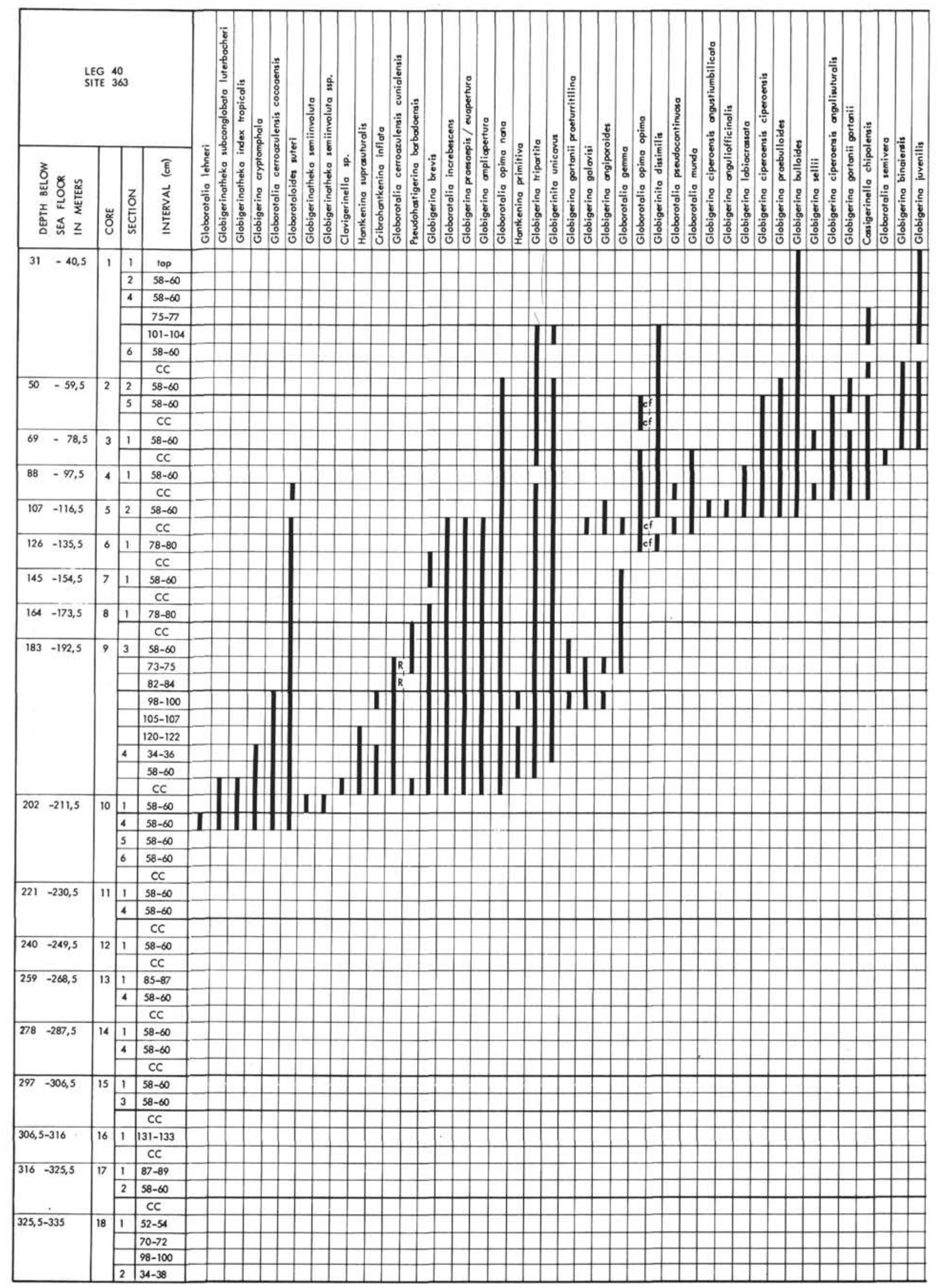

Figure 9b. Distribution of lower Paleocene to middle Miocene planktonic foraminifers at Site 363. 


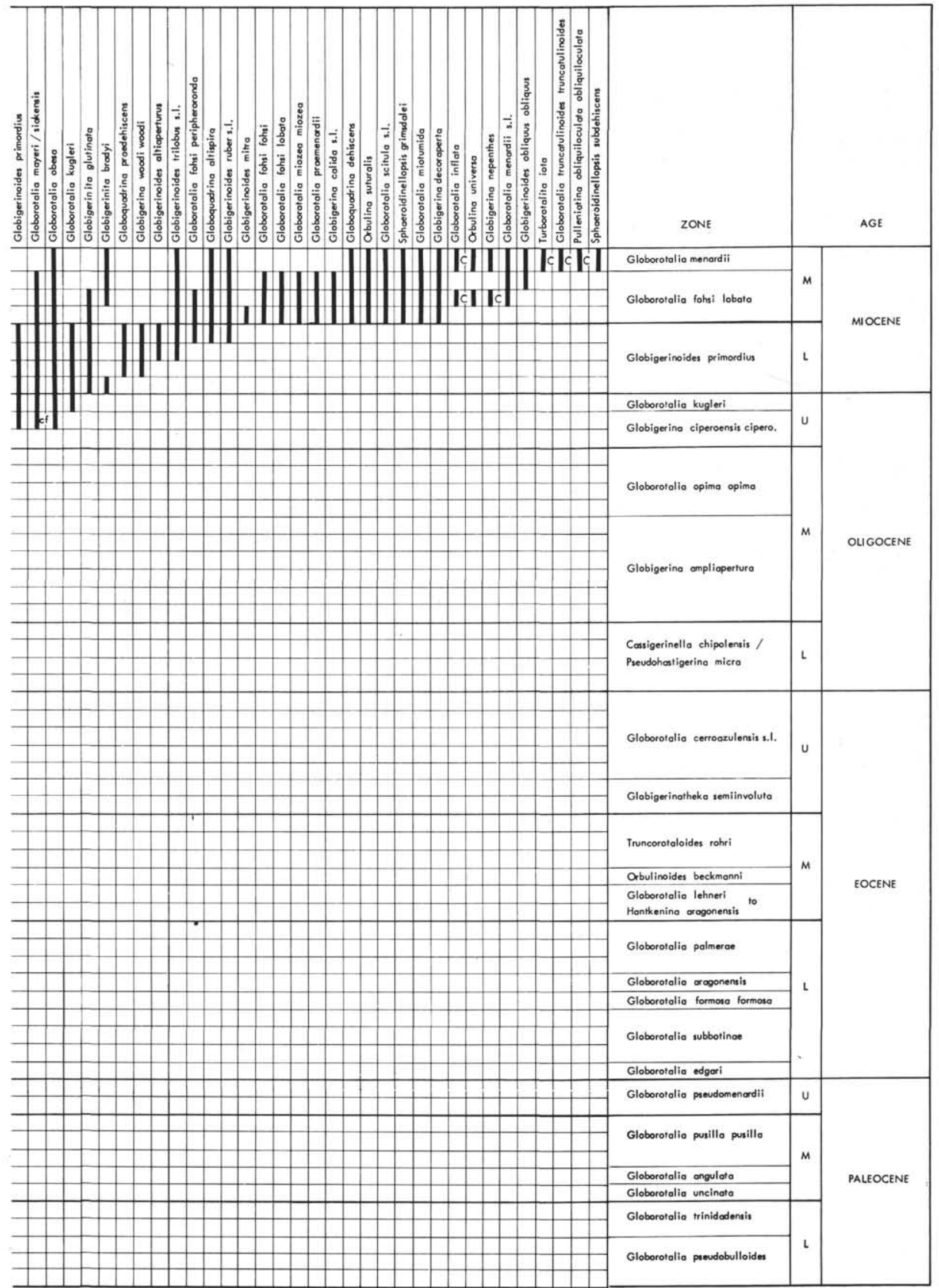

Figure 9b. (Continued). 


\begin{tabular}{|c|c|c|c|c|}
\hline CORE & SECTION & PRESERVATION & ZONE & AGE \\
\hline 1 & $\begin{array}{c}0 \text { very top } \\
\text { top } \\
\text { CC }\end{array}$ & & $\begin{array}{r}\text { Globorotalia truncatulinoides } \\
\text { truncatulinoides }\end{array}$ & PLEISTOCENE \\
\hline \multirow[t]{2}{*}{2} & \multirow{2}{*}{$\begin{array}{cc}1 & 58-60 \\
3 & 58-60 \\
\text { CC }\end{array}$} & & & \\
\hline & & + & Globorotalia miocenica & \multirow[b]{2}{*}{ PLIOCENE } \\
\hline 3 & $\begin{array}{cc}1 & 58-60 \\
4 & 58-60 \\
& C C\end{array}$ & + & Globorotalia margaritae & \\
\hline 4 & $\begin{array}{c}158-60 \\
C C\end{array}$ & + & Neogloboquadrina dutertrei & UPPER MIOCENE \\
\hline \multirow[t]{2}{*}{5} & \multirow{2}{*}{$\begin{array}{cc}2 & 58-60 \\
4 & 58-60 \\
& C C\end{array}$} & \multirow{2}{*}{$\square$} & & \\
\hline & & & Globorotalia fohsi periphero & MIDDLE MIOCENE \\
\hline 6 & $\begin{array}{cc}1 & 58-60 \\
6 & 58-60 \\
& C C\end{array}$ & & & \\
\hline \multirow[t]{2}{*}{7} & \multirow{2}{*}{$\begin{array}{c}58-60 \\
C C\end{array}$} & \multirow{2}{*}{ 문 } & & \\
\hline & & & & MIDDLE EOCENE \\
\hline \multirow[t]{3}{*}{8} & \multirow{3}{*}{$\begin{array}{cc}1 & 58-60 \\
4 & 58-60 \\
6 & 58-60 \\
& C C\end{array}$} & $\square$ & & \\
\hline & & 卷 & $\begin{array}{l}\text { Globorotalia palmerae to } \\
\text { Globorotalia aragonensis }\end{array}$ & \multirow{3}{*}{ LOWER EOCENE } \\
\hline & & + & Globorotalia formosa formosa & \\
\hline \multirow[t]{2}{*}{9} & \multirow{2}{*}{$\begin{array}{cc}1 & 53-55 \\
3 & 58-60 \\
C C\end{array}$} & \multirow[t]{2}{*}{+} & $\begin{array}{l}\text { Globorotalia subbotinae } \\
\text { Globorotalia edgari }\end{array}$ & \\
\hline & & & Globorotalia velascoens is & UPPER PALEOCENE \\
\hline \multirow[t]{3}{*}{10} & \multirow{3}{*}{$\begin{array}{cc}1 & 58-60 \\
3 & 58-60 \\
4 & 58-62 \\
& \text { CC }\end{array}$} & \multirow{3}{*}{$\begin{array}{l}\square \\
* \\
* \\
*\end{array}$} & & \\
\hline & & & Globorotalia angulata & MIDDLE PALEOCENE \\
\hline & & & Globorotalia trinidadensis & LOWER PALEOCENE \\
\hline
\end{tabular}

Figure 10. Site 364: Preservation of planktonic foraminifers.

site. The genus Hantkenina is represented by rare badly preserved specimens (an additional argument for strong dissolution effects). Dr. D.G. Jenkins kindly made some comments on the comparison between the Eocene fauna of Site 360 and the Eocene of New Zealand, though he thought that such a comparison is difficult because of the much lower species diversity at Site 360 . $\mathrm{He}$ noted that "in the Site 360 Upper Eocene, the dominant Globigerinatheka is $G$. subconglobata luterbacheri, whereas in New Zealand it is G. index index," and also that the "initial appearance of Chiloguembelina cubensis is later in the upper Eocene as compared with New Zealand (Jenkins, 1971)." Globigerina primitiva extends higher, to the top of the middle Eocene at Site 360 compared with Site 363, where it becomes extinct just before the beginning of the middle Eocene. The extension in range of certain species is longer in cooler than in warmer waters. This can be shown for Globigerina primitiva and a number of Globigerinatheka species. Hantkenina australis, originally recorded from New Zealand, was found in sediments of Holes $362 \mathrm{~A}$ and 363 . Species described originally from the Alpine-Mediterranean province such as Globigerinatheka subconglobata luterbacheri (Holes 360, 362A, 363) and Globorotalia cerroazulensis cunialensis Holes 362A, 363) are also well represented in the South Atlantic.

There are indications that the differentiation of the subspecies of the Globorotalia cerroazulensis lineage began at Site 363 earlier than in the Northern Hemisphere and the North Pacific, where the first appearance of each subspecies occurs apparently later and at the same level in all the sections studied (Toumarkine and Bolli, 1970: Toumarkine, 1975).

At Site 363 a similar early evolution may also occur in Globigerina ampliapertura, which is assumed to have evolved from Globorotalia increbescens (Blow and Banner, 1962). The first $G$. ampliapertura already appears in Sample 9, CC, at the top of the Globigerinatheka semiinvoluta Zone, together with Globigerina increbescens.

Some temperate species such as Globorotalia aragonensis caucasica and Globigerinatheka subconglobata luterbacheri are abundant in sediments of Holes 362A 
and 363. Unfortunately it is not possible to determine whether they continue north as far as Site 364 because dissolution has destroyed a large part of the Eocene faunas at that site.

Oligocene was recovered from Holes $360,362 \mathrm{~A}$, and 363. Faunal differences between these sites are less marked than they are for the Eocene. This is seen in a less diverse planktonic foraminifer association which is also more resistant to dissolution.

The presence of Globigerina angiporoides, G. brevis, Globorotalia labiacrassata, G. gemma, G. munda, G. pseudocontinuosa, G. semivera, and Globorotaloides testarugosa, which originally were described from New Zealand and Southern Australia (Jenkins, 1960, 1971), shows the strong influence of the Austral-New Zealand faunal province. It is of special interest that most of the species were much more cosmopolitan in the Oligocene than originally thought (Jenkins, personal communication). Globigerina testarugosa is limited to Site 360 . Globigerina binaiensis, which was thought to be confined to the tropical portion of the Indo-Pacific province, occurs in the upper Oligocene of Site 363. This is evidence for a connection between the IndoPacific and the South Atlantic province.

In the sections of Holes 360, 362A, and 363, Cassigerinella chipblensis appears late, only within the Globorotalia opima opima Zone. This is probably due rather to geographic factors than to selective solution, as is indicated by the presence in the lower and middle Oligocene of Chiloguembelina cubensis, a species, according to Fleisher (1975), very sensitive to dissolution.

The first appearance of Globigerinoides primordius, datum for the base of the Miocene, occurs at Site 363 already at the top of the Globigerina ciperoensis ciperoensis Zone, earlier than in some other areas.

The highest cores of Holes 362A (Core 1), 363 (Sample 2-2, 58-60 cm), and 364 (Cores 1-4) are of Neogene age. At \$ite 363, above a hiatus between the Globigerinoides primordius Zone and the Globorotalia fohsi lobata Zone, he Globorotalia fohsi group appears, represented by the subspecies $G$. fohsi peripheroronda, $G$. fohsi fohsi, and $G$. fohsi lobata. The higher fohsi subspecies ( $G$. fohsi fohsi and $G$. fohsi lobata) are known from tropical waters but are absent from the Mediterranean area. The presence at the same time at Site 363 of the temperate water Globorotalia miotumida and $G$. miozea, and tropical $G$. fohsi subspecies, points to mixing or overlap of tropical and temperate waters at the Site 363 area on Walvis Ridge.

The few recognized Neogene zones of the Angola Basin Site 364 contain species generally present in tropical areas. The tropical zonal scheme can therefore be readily applied here.

\section{ACKNOWLEDGMENT}

The material collected during DSDP Leg 40 was made available by H.M. Bolli, who has also read and discussed the manuscript. D.G. Jenkins gave much advice during the investigations, and some aspects of the wall structures were discussed with Marie-Pierre Aubry. The Geology Department of the Swiss Federal Institute of Technology, Zurich, provided laboratory facilities and technical help. The charts were typed by Miss Sonja Solcà and drawn by A. Uhr. The scanning electron micrographs were taken by H.E. Franz; U. Gerber prepared the photographs for the plates and tables. To all of them the writer wishes to express her sincere thanks.

The present study is a contribution to the I.G.C.P. Project No. 145: "Establishing of a biostratigraphic scale of the West Africa sedimentary basins and their relations to the other basins of Africa, the Americas and the Tethys."

\section{REFERENCES}

Berger, W.H., 1968. Planktonic foraminifera: selective solution and paleoclimatic interpretation: Deep-Sea Res., v. 15, p. 31 .

1970. Planktonic foraminifera: selective solution and the lysocline: Marine Geol. v. 8, p. 111.

1972. Deep sea carbonates: dissolution facies and age-depth constancy: Nature, v. 236, p. 392.

Berger, W.H. and von Rad, U., 1972. Cretaceous and Cenozoic sediments from the Atlantic Ocean. In Hayes, D.E., Pimm, A.C., et al., Initial Reports of the Deep Sea Drilling Project, Volume 14: Washington (U.S. Government Printing Office), p. 787.

Bizon, G. and Bizon, J.J., 1972. Atlas des principaux foraminiferes planctoniques du bassin Mediterranéen-Oligocène à Quaternaire: Paris (Editions Technip), p. 1-316.

Blow, W.H., 1969. Late middle Eocene to Recent planktonic foraminiferal biostratigraphy. In Brönnimann, P. and Renz. H.H (Eds.), Internatl. Conf. Plankt. Microfossils, Proc. 1st., v. 1, Leiden (E.J. Brill), p. 199.

Blow, W.H. and Banner, F.T., 1962. The Mid-Tertiary (upper Eocene to Aquitanian) Globigerinaceae. In Eames, F.E., Banner, F.T., Blow, W.H., and Clarke, W.J., (eds.) Fundamentals of Mid-Tertiary stratigraphical correlation: Cambridge (Cambridge Univ. Press), p. 61.

Bolli, H.M., 1957a. The genera Globigerina and Globorotalia in the Paleocene-Lower Eocene Lizard Springs formation of Trinidad, B.W.I.: U.S. Nat. Mus. Bull. 215, p. 61. 1957b. Planktonic foraminifera from the Oligocene-Miocene Cipero and Lengua formations of Trinidad, B.W.I.: U.S. Nat. Mus. Bull. 215, p. 97. 1957c. Planktonic foraminifera from the Eocene Navet and San Fernando formations of Trinidad, B.W.I.: U.S. Nat. Mus. Bull. 215, p. 155.

1966. Zonation of Cretaceous to Pliocene marine sediments based on planktonic foraminifera: Bol. Inform., Asoc. Venez. Geol., Min., Petrol., v. 9, p. 3. 1972. The Genus Globigerinatheka Broennimann: J. Foram. Res., v. 2, p. 109.

Brönnimann, P., 1950. The Genus Hantkenina Cushman in Trinidad and Barbados, B.W.I.: J. Paleontol., v. 24, p. 397.

Cita, M.B., 1970. Observations sur quelques aspects paléoécologiques de sondages subocéaniques effectués dans l'Atlantique nord: Rev. Micropal., v. 12, p. 187. 1971a. Biostratigraphy, chronostratigraphy and paleoenvironment of the Pliocene of Cape Verde (North Atlantic). Rev. Micropal., v. 14, p. 17.

1971b. Paleoenvironmental aspects of DSDP Legs I-IV: 2nd Plankt. Conf. Proc., p. 251.

Cita, M.B. and Gartner, S., Jr., 1971. Deep sea Upper Cretaceous from the Western North Atlantic: 2nd Plankt. Conf. Proc., p. 287.

Fleisher, R.L., 1975. Oligocene foraminiferal biostratigraphy, Central North Pacific Ocean, DSDP Leg 32. In Larson, 


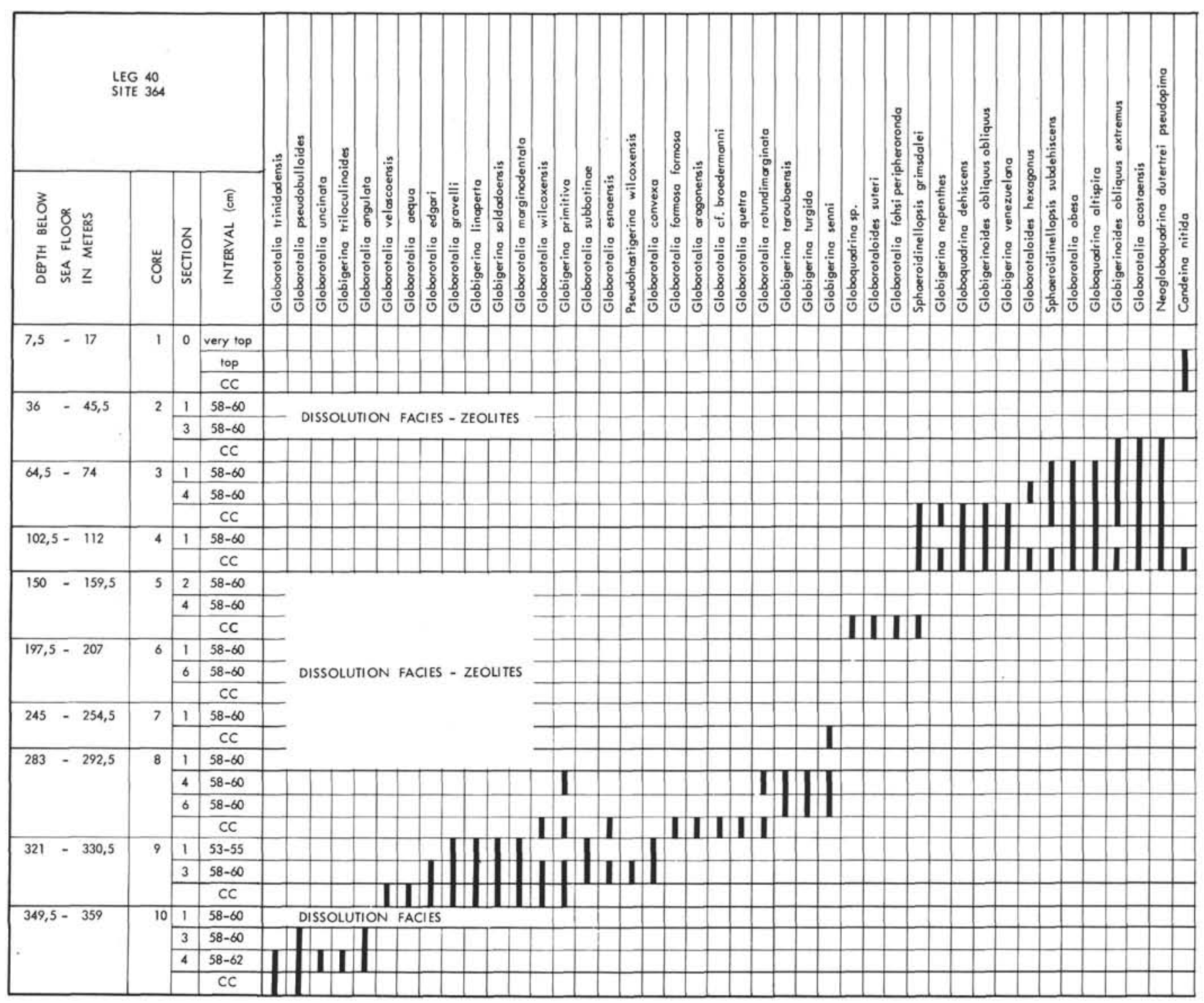

Figure 11. Distribution of lower Paleocene to Pleistocene planktonic foraminifers of Site 364.

R.L., Moberly, R., et al., Initial Reports of the Deep Sea Drilling Project, Volume 32: Washington (U.S. Government Printing Office), p. 753.

Jenkins, D.G., 1967. Planktonic foraminiferal zones and new taxa from the Lower Miocene to the Pleistocene of New Zealand: New Zealand J. Geol. Geophys., v. 10, p. 1064. , 1970. Foraminiferida and New Zealand Tertiary Biostratigraphy Rev. Espan. Micropal., v. 2, p. 13. , 1971. New Zealand Cenozoic planktonic foraminifera: New Zealand Geol. Surv. Paleont. Bull. 42. 1972. Planktonic foraminiferal biostratigraphy of the eastern equatorial Pacific-DSDP Leg 9. In Hayes, J.D., et al., Initial Reports of the Deep Sea Drilling Project, Volume 9: Washington (U.S. Government Printing Office), p. 1060.

Jenkins, D.G. and Orr, W.N., 1971. Cenozoic planktonic foraminiferal zonation and the problem of test solutions: Rev. Espan. Micropal., v. 3, p. 301.

Luterbacher, H.P., 1964. Studies in some Globorotalia from the Paleocene and Lower Eocene of the Central Apennines: Ecolog. Geol. Helv., v. 57, p. 631.
1975. Planktonic foraminifera of the Paleocene and early Eocene, Possagno section (Treviso, Northern Italy): Schw. Pal. Abh., v. 97, p. 57.

Premoli-Silva, I. and Bolli, H.M., 1973. Late Cretaceous to Eocene planktonic foaminifera and stratigraphy of Leg 15 sites in the Caribbean Sea. In Edgar, N.T., Saunders, H.B., et al., Initial Reports of the Deep Sea Drilling Project, Volume 15: Washington (U.S. Government Printing Office), p. 449.

Proto Decima, F. and Bolli, H.M., 1970. Evolution and variability of Orbulinoides beckmanni (Saito): Ecolog. Geol. Helv., v. 63, p. 883.

Rögl, F. and Bolli, H.M., 1973. Holocene to Pleistocene Planktonic Foraminifera of Leg 15, Site 147 (Cariaco Basin (trench) Caribbean Sea) and their climatic interpretation. In Edgar, N.T., Saunders, H.B., et al., Initial Reports of the Deep Sea Drilling Project, Volume 15: Washington (U.S. Government Printing Office), p. 553 .

Saunders, H.B., Beaudry, F.M., Bolli, H.M., Rögl, F., Riedel, W.R., Sanfilippo, A., and Premoli-Silva, I., 1973. Paleocene to Recent microfossil distribution in the marine 


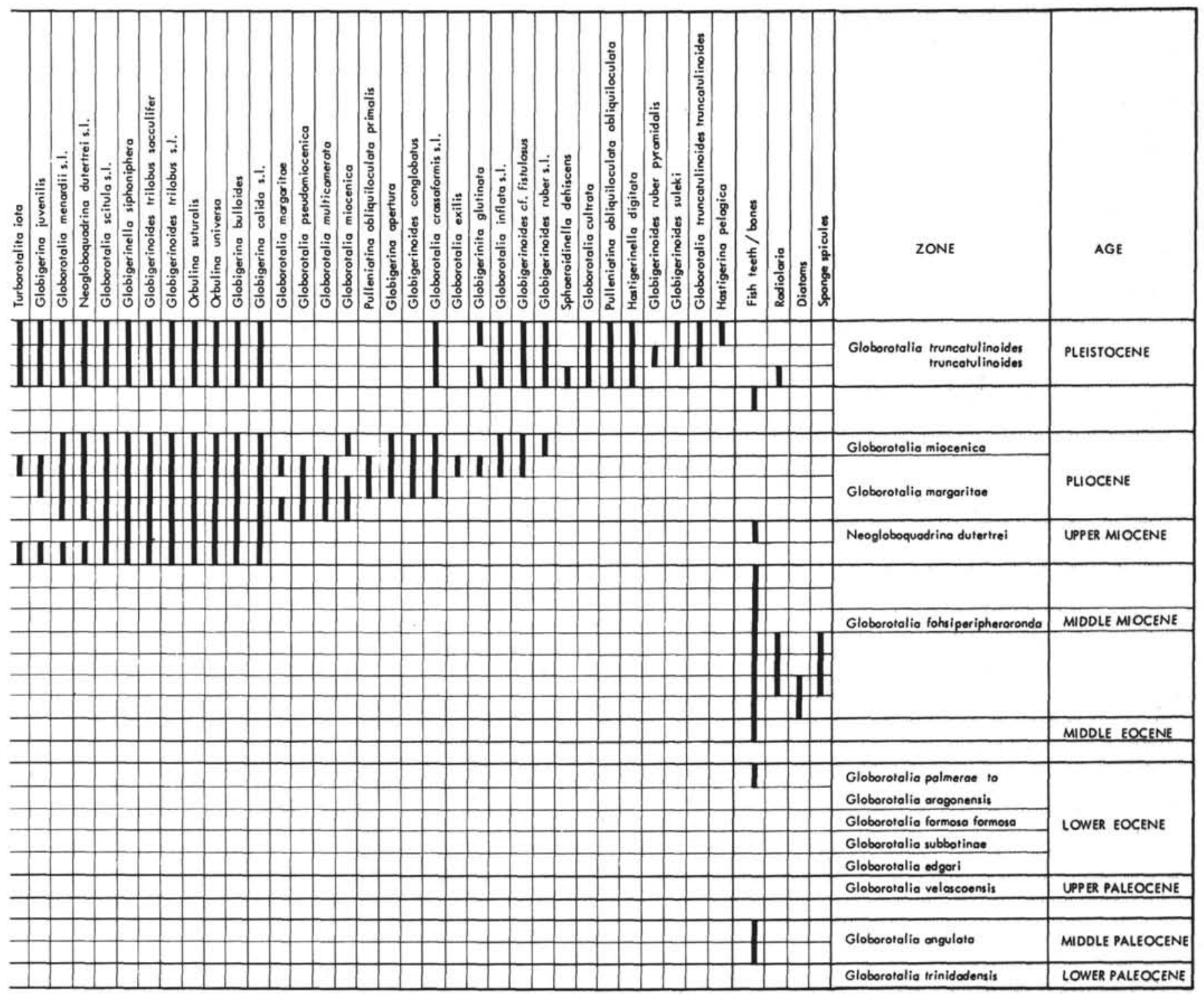

Figure 11. (Continued).

and land areas of the Caribbean. In Edgar, N.T., Saunders, J.B., et al., Initial Reports of the Deep Sea Drilling Project, Volume 15: Washington (U.S. Government Printing Office), p. 769.

Stainforth, R.M., Lamb, J.L., Luterbacher, H., Beard, J.H., and Jeffords, R.M., 1975. Cenozoic planktonic foraminiferal zonation and characteristics of index forms: Univ. Kansas, Paleontol. Contrib.

Subbotina, N.M., 1953. Globigerinidae, Hantkeninidae et Globorotaloidae: Foraminiferes fossiles d'USSR: Trudy VNIGRI 76, p. 296.

Sztrakos, K., 1974. Paleogene planktonic foraminiferal zones in Northeastern Hungary: Fragm. Min. Pal., v. 5, p. 29.
Toumarkine, M., 1975. Middle and Late Eocene planktonic foraminifera from the Northwestern Pacific, Leg 32 of the Deep Sea Drilling Project. In Larson, R.L., Moberly, R., et al., Initial Reports of the Deep Sea Drilling Project, Volume 32: Washington (U.S. Government Printing Office), p. 735 .

Toumarkine, M. and Bolli, H.M., 1970. Evolution de Globorotalia cerroazulensis (Cole) dans l'Eocène moyen et supérieur de Possagno (Italie): Rev. Micropal., v. 13, p. $131-145$.

1975. Foraminiferes planctoniques de l'Eocène moyen et supérieur de la coupe de Possagno: Schw. Pal. Abh., v. 97, p. 69. 


\section{PLATE 1}

Figures 1, 2 Globorotalia pseudobulloides (Plummer). 80×. Sample 364-10-4, 58$60 \mathrm{~cm}$. Globorotalia angulata Zone; middle Paleocene.

1. Spiral view (C-33616).

2. Umbilical view (C-33617).

Figures 3-5 Globigerina triloculinoides Plummer. Sample 364-10-4, 58-60 cm. Globorotalia angulata Zone; middle Paleocene.

3. Spiral view (C-33618), 100X.

4. Detail of Fig. 1; penultimate chamber, $500 \times$.

5. Umbilical view (C-33619), 100X.

Figures 6-8 Globorotalia inconstans (Subbotina). Sample 363-17 CC. Globorotalia trinidadensis Zone; lower Paleocene.

6. Spiral view (C-33620), 80X.

7. Spiral view (C-33621), $80 \times$.

8. Detail of Fig. 7; final chamber, 1000x.

Figures 9-11 Globorotalia trinidadensis (Bolli). Sample 363-17, CC. Globorotalia trinidadensis Zone: lower Paleocene.

9. Spiral view (C-33622), 80X.

10. Spiral view (C-33623), $80 \times$

11. Detail of Fig. 10; penultimate chamber, 1000×.

Figures 12-15 Globorotalia praecursoria (Morozova). Sample 363-17, CC. Globorotalia trinidadensis Zone: Lower Paleocene.

12. Spiral view (C-33624), 80X.

13. Umbilical view (C-33625), $80 \times$.

14. Spiral view (C-33626), $80 \times$

15. Detail of Fig. 14; final chamber, 1000x.

Figure 16 Globorotalia uncinata Bolli $80 \times$. Sample 363-17-1, 87-89 cm. Globorotalia angulata Zone; middle Paleocene. Umbilical view (C-33627).

Figures 17, 18 Globorotalia conicotruncata Subbotina. 80×. Sample 363-17-1, 87$89 \mathrm{~cm}$. Globorotalia angulata Zone; middle Paleocene.

17. Spiral view (C-33628).

18. Side view (C-33629).

Figures 19, 20 Globorotalia tadjikistanensis Bykova. 80×. Sample 363-17-1, 87-89 $\mathrm{cm}$. Globorotalia angulata Zone; middle Paleocene.

19. Spiral view (C-33630).

20. Side view (C-33631).

Figure $21 \quad$ Globorotalia angulata (White). 80X. Sample 363-17-1 $87-89 \mathrm{~cm}$. Globorotalia angulata Zone; middle Paleocene. Spiral view (C33632).

Figure 22 Globorotalia pseudomayeri Bolli. 100×. Sample 363-11, CC. Globorotalia palmerae Zone; lower Eocene. Spiral view (C-33633).

Figures 23, 24 Globorotalia lensiformis Subbotina. Sample 363-13, CC. Globorotalia subbotinae Zone; lower Eocene.

23. Spiral view. (C-33634), 80x.

24. Detail of Fig. 23; final chamber, showing coarse granulations and large pores, $500 \times$. 
PLATE 1

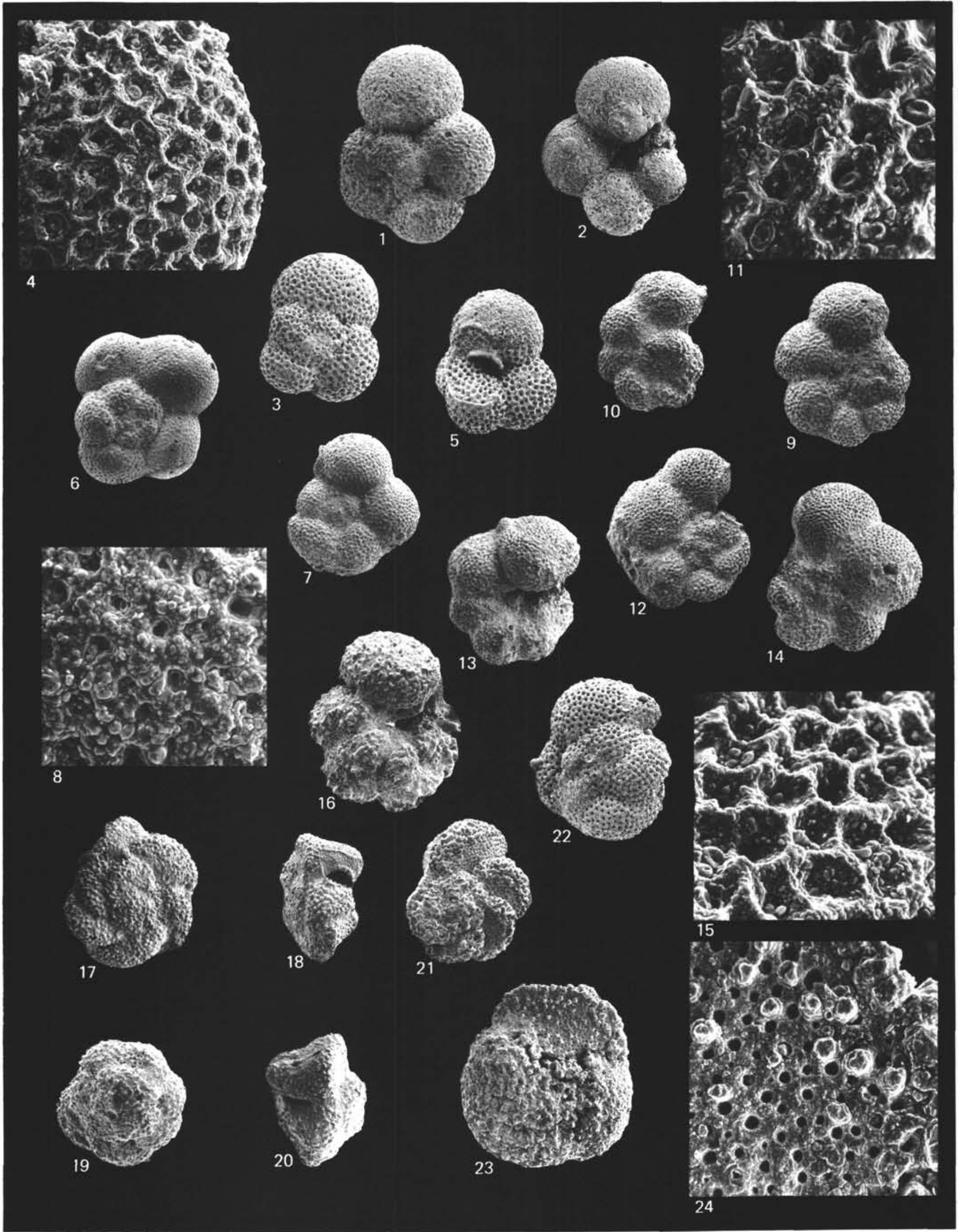




\section{PLATE 2}

Figures 1, 2 Hantkenina longispina Cushman. Sample 363-10-4, $58-60 \mathrm{~cm}$. Truncorotaloides rohri Zone; middle Eocene.

1. Side view (C-33635), 75X.

2. Detail of a spine of Fig. 1, 500X.

Figures 3, 4 Hantkenina longispina Cushman. Sample 363-11-1, $58-60 \mathrm{~cm}$. Globorotalia lehneri to Hantkenina aragonensis Zone: middle Eocene.

3. Side view (C-33636), 70X.

4. Detail of spine of Fig. 3, 500X.

Figure 5 Hantkenina liebusi Shokhina. 100×. Sample 36310, CC. Orbulinoides beckmanni Zone: middle Eocene. Side view (C-33637).

Figures 6-8 Hantkenina australis Finlay. 6, 7. Sample 362A-101, $65-67 \mathrm{~cm}$. Truncorotaloides rohri Zone to Orbulinoides beckmanni Zone: middle Eocene. 8. Sample 363-9, CC. Globigerinatheka semiinvoluta Zone: upper Eocene.

6. Side view (C-33638), $75 \times$.

7. Side view (C-33639), $75 \times$.

8. Side view (C-33640), 80X.

Figures 9-12 Hantkenina primitiva Cushman and Jarvis. 9, 10. Sample 363-9-4, 58-60 cm. 12. Sample 363-94, $34-35 \mathrm{~cm}$. Globorotalia cerroazulensis s.I. Zone: upper Eocene.

9. Side view (C-33641), 100X.

10. Side view (C-33642), 100X.

11. Details of a spine of Fig. 10, $500 \times$.

12. Side view (C-33643), 100×.

Figure 13 Hantkenina alabamensis Cushman $75 \times$. Sample 363-9-4, 58-60 cm. Globorotalia cerroazulensis s.1. Zone: upper Eocene (C-33644).

Figures 14-17 C'ribrohantkenina inflata (Howe). 14, 15. 17. Sample 363-9-4, 58-60 cm. 16. Sample 363-9-4, 34-36 $\mathrm{cm}$. Globorotalia cerroazulensis s.l. Zone: upper Eocene.

14. Side view (C-33645), $75 \times$.

15. Edge view (C-33646), showing arched row of supplementary areal apertures in addition to the primary equatorial aperture, still visible on the figure, $75 \times$.

16. Edge view (C-33647), showing development of a supplementary aperture above the equatorial one, $150 \times$.

17. Edge side view (C-33648), showing the beginning of the development of the supplementary aperture, $75 \times$.

Figures 18, 19 Hantkenina suprasuturalis Brönnimann. Sample 363-9, CC. Globigerinatheka semiinvoluta Zone: upper Eocene.

18. Side view (C-33649), 62X.

19. Detail of the wall test of the final chamber, $1000 \times$. 
PLATE 2

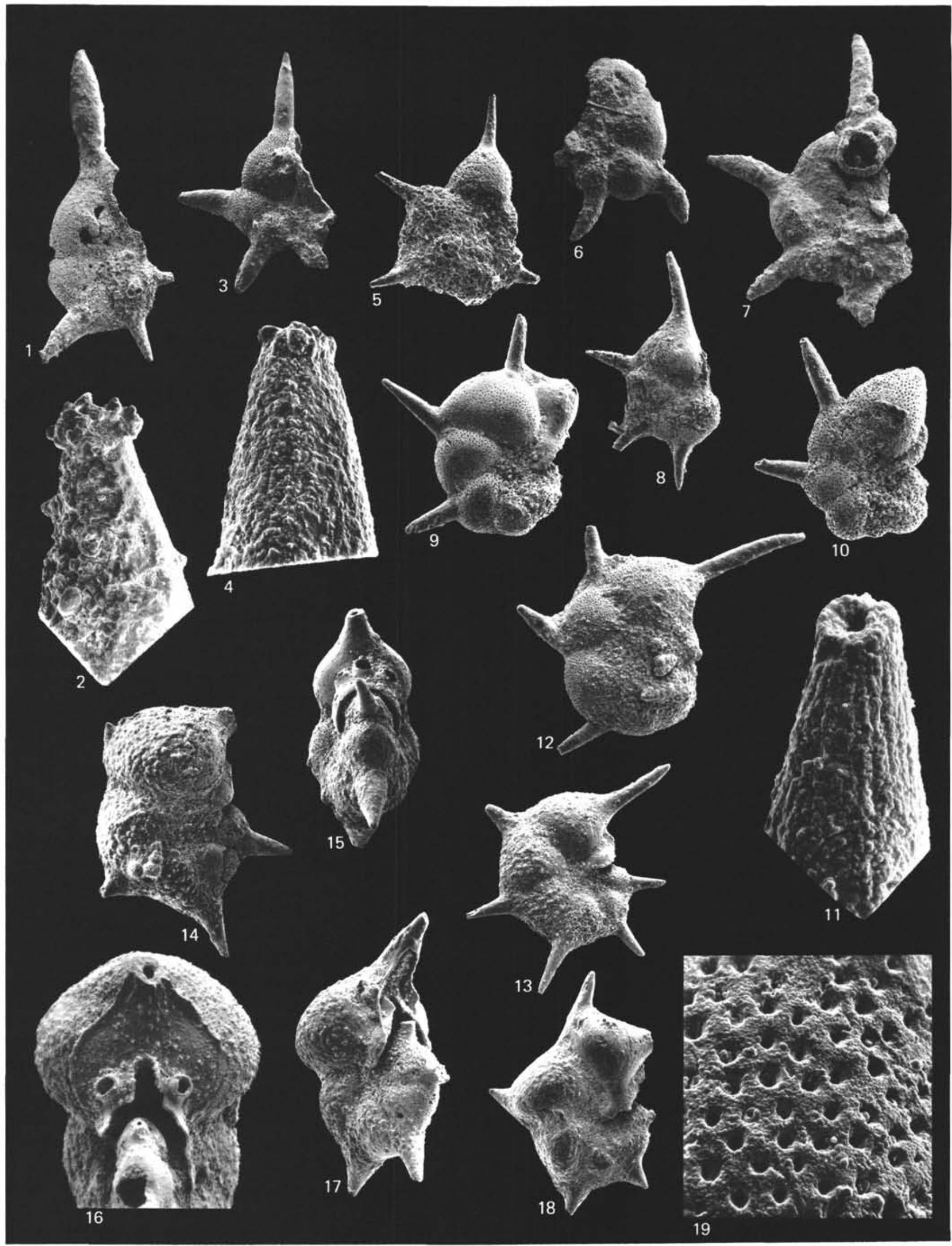




\section{PLATE 3}

Figures 1-3 Globigerinatheka subconglobata subconglobata (Shutskaya).

1, 3. $100 \times$. Samples 360-45, CC. Truncorotaloides rohri to Globorotalia lehneri Zone; middle Eocene.

2. $80 \times$. Sample $363-11-1,58-60 \mathrm{~cm}$. Globorotalia lehneri to Hantkenina aragonensis Zone; middle Eocene.

1. Spiral view (C-33650).

2. Spiral view (C-33651); specimen with small ultimate chamber.

3. Umbilical view (C-33652).

Figures 4-5 Globigerinatheka subconglobata curryi Proto Decima and Bolli. Sample 363-11-4, 58-60 cm. Globorotalia lehneri to Hantkenina aragonensis Zone; middle Eocene.

4. Side view (C-33653), 100X.

5. Spiral view (C-33654). Specimen with one bulla on right side, $80 \times$.

Figures 6-8 Globigerinatheka subconglobata euganea Proto Decima and Bolli. Sample 363-10, CC. Orbulinoides beckmanni Zone; middle Eocene.

6. Spiral view (C-33655); specimen with three large bullae, $75 \times$.

7. Spiral view (C-335656), spherical specimen with very large ultimate chamber and three bullae covering apertures, $100 \times$.

8. Detail of Fig. 7; thin walled bulla with two thick rimmed apertures, $250 \times$.

Figures 9-13 Orbulinoides beckmanni (Saito). Sample 363-10, CC. Orbulinoides beckmanni Zone: middle Eocene.

9. (C-33657). Specimen with sutural apertures, $75 \times$.

10. Detail of Fig. 9; sutural apertures, $250 \times$.

11. Detail of Fig. 9; recrystallization more pronounced around apertures, 700×.

12. (C-33658), very large specimen with large sutural apertures, $75 \times$.

13. Detail of Fig. 12, one sutural aperture, $250 \times$.

Figures 14,15 Globigerinatheka subconglobata luterbacheri Bolli. Sample 363-10-1, 58-60 cm. Globigerinatheka semiinvoluta Zone; upper Eocene.

14. (C-33659) Spiral view of a specimen with three bullae, all visible on figure, $75 \times$.

15. Detail of Fig. 14; thick-walled bulla with pore size about the same as that of the chambers, $250 \times$. 
PLATE 3

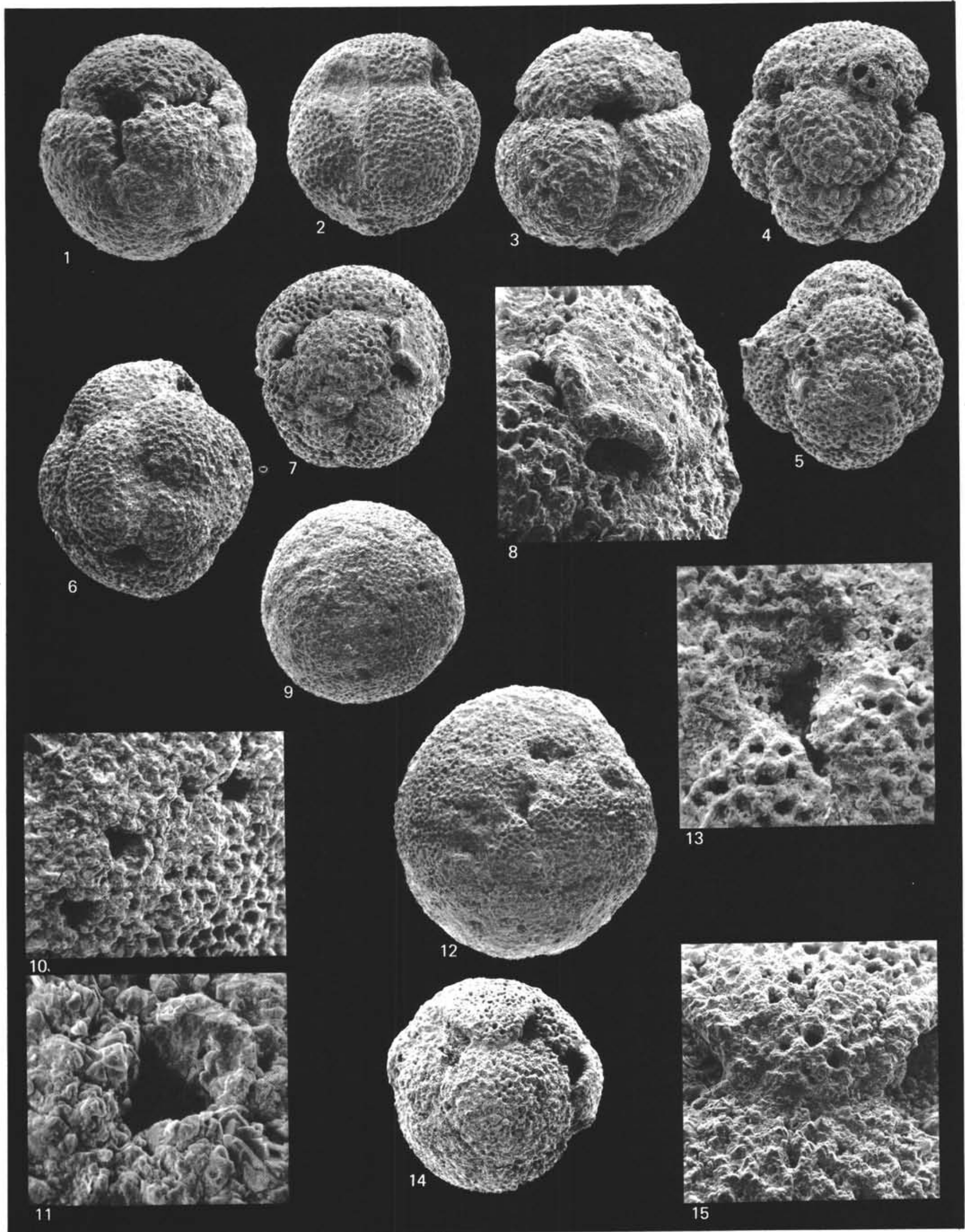




\section{PLATE 4}

Figures 1-4 Globigerinatheka subconglobata luterbacheri Bolli. 1. Sample 360-35, CC. Globorotalia cerroazulensis s.l. to Globigerinatheka semiinvoluta Zone: upper Eocene.

2, 4. Sample 363-10-4 58-60 cm. Truncorotaloides rohri Zone. middle Eocene.

1. (C-33660), large specimen with three bullae covering apertures, $75 \times$.

2. (C-33661) side view of a specimen with one large bulla on the umbilical side, $75 \times$.

3. Detail of Fig. 2. Large, thin-walled bulla with large pores covering aperture, bordered by a thin rim. Some recrystallization is visible around the large pores of the chamber wall, 150X.

4. Specimen with one bulla (C-33662), $75 \times$.

Figures 5-7 Globigerinatheka mexicana mexicana (Cushman).

5. From Sample 363-11-1, 58-60 cm. Globorotalia lehneri to Hantkenina aragonensis Zone. 6. Sample 363-10, CC. Orbulinoides beckmanni Zone. 7. Sample 363-10-5, 58-60 cm. Truncorotaloides rohri Zone, middle Eocene.

5. Umbilical view of a specimen with three apertures in last chamber; two are visible on the figure (C-33663), 75X.

6. Spiral view - one aperture visible, bordered by a thin rim (C-33664), $100 \times$.

7. Umbilical view-two apertures visible, bordered by a thick rim (C33665), 100x.

Figures 8-12 Globigerinatheka mexicana barri Brönnimann.

8. Sample $360-43$, CC. Truncorotaloides rohri to Globorotalia lehneri Zone: middle Eocene.

9. Sample 363-10-1, 58-60 cm. Globigerinatheka semiinvoluta Zone: upper Eocene.

11. Sample $363-11-1,58-60 \mathrm{~cm}$. Globorotalia lehneri to Hantkenina aragonensis Zone; middle Eocene.

8. Specimen with one large bulla with strong apertural rims (C-33666), $100 \times$.

9. Small specimen with two thin-walled, finely perforated, bullae. One high arched rimmed aperture (C-33667), 100X.

10. Detail of Fig. 9. Coarsely perforated chamber wall with coarse short spines, and thin bulla, $250 \times$.

11. Specimen with two bullae (C-33668), 100×.

12. Detail of Fig. 11. Bulla with pore size finer than that of the chamber. Two apertural rims $250 \times$.

Figures 13-16 Globigerinatheka index tropicalis (Blow and Banner). Sample 363-10-1, $58-60 \mathrm{~cm}$. Globigerinatheka semiinvoluta Zone: upper Eocene.

13. Specimen with three apertures. One is visible. Flat ultimate chamber (C-33669), 75×.

14. Detail of Fig. 13. Coarsely perforated wall of last chamber $1000 \times$.

15. Detail of Fig. 13; view of large aperture, 150x.

16. Elongated specimen with two large apertures (C-33670), $75 \times$.

Figures 17-20 Globigerinatheka index rubriformis (Subbotina) Sample 363-11-1, 58-60 $\mathrm{cm}$. Globorotalia lehneri to Globigerinatheka subconglobata subconglobata Zone: middle Eocene. High spired subspecies.

17. Oblique spiral view (C-33671), $75 \times$.

18. Umbilical view, (C-33672), $75 \times$.

19. Side view. Last chamber with two apertures (C-33673), 75×.

20. Detail of Fig. 19. Granular surface showing coarse perforations, $1000 \times$. 


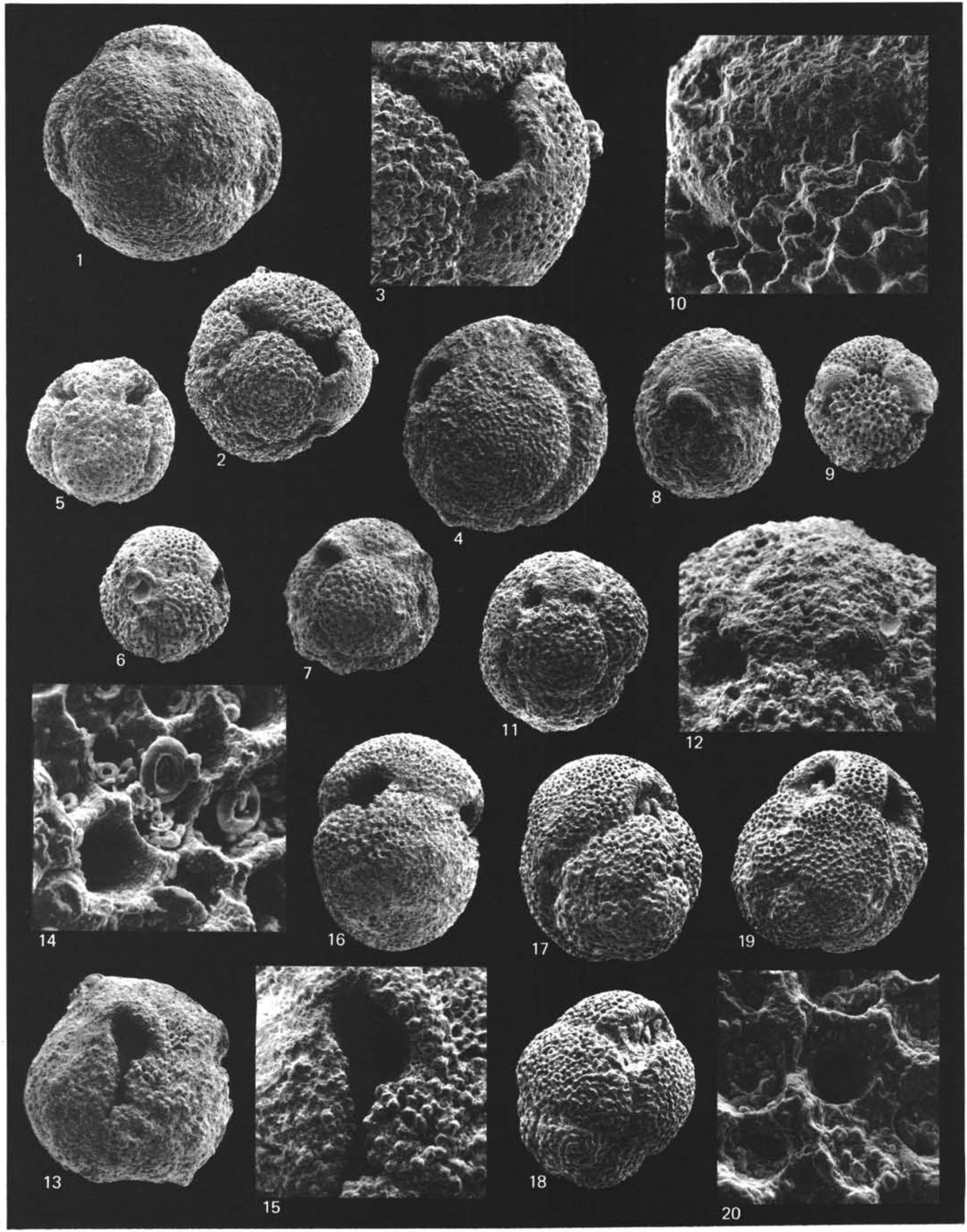




\section{PLATE 5}

Figures 1-9 Globigerinatheka index index (Finlay). Fig. 1: 50×. Fig. 2: $1000 \times$. Fig. 3, 6: $80 \times$. Fig. 4, 9: 75×. Fig. 5, 8: 70×. Fig. 7: $100 \times$.

3. Sample 363-10, CC. Orbulinoides beckmanni Zone: middle Eocene.

1, 2, 4-9. Sample 363-10-4, 58-60 cm. Truncorotaloides rohri Zone: middle Eocene.

1. Specimen with large inflated ultimate chamber and very high arched apertures (C-33674).

2. Detail of Fig. 1. Very large perfores with some superficial recrystallization around them.

3. Umbilical view (C-33675).

4, 5. Elongate specimens with large ultimate chamber and very large high arched and wide apertures (C-33676, C-33677).

6-9. Specimens with one very large single aperture on the umbilical side (C-33678, C33679, C-33680, C-33681).

Figures 10-14 Globigerinatheka semiinvoluta (Keijzer). Sample 363-10-1, 58-60 cm. Globigerinatheka semiinvoluta Zone; upper Eocene.

10,12 . Small specimens with two apertures (C33682, C-33684), 100x.

11. Small specimen with three apertures (C33683), 100X.

13. Detail of Fig. 12. Large pores surrounded by coarse spines, $200 \times$.

14. Detail of Fig. 12. Very well preserved wall structure, $2500 \times$.

Figures 15-21 Globigerinatheka semiinvoluta ssp. Fig. 15: 80×.

Fig. 16, 17, 19-21: 100×. Fig. 18: 1000×.

21. Sample 360-35, CC. Globorotalia cerroazulensis s.1. to Globigerinatheka semiinvoluta Zone; upper Eocene.

15-20. Sample 363-10-1, 58-60 cm. Globigerinatheka semiinvoluta Zone; upper Eocene. Small specimens with one single aperture on the umbilical side and with a very large last chamber partly covering the umbilical area.

15. Umbilical view of a nearly spherical specimen (C-33685).

16. Spiral view (C-33686).

17. Side view (C-33687). Spherical specimen.

18. Detail of Fig. 17. Wall structure.

19. Specimen with ultimate chamber much larger than early part. Side view (C-33688).

20. Side view (C-33689).

21. Spiral view. Small spherical specimen (C33690). 
PLATE 5

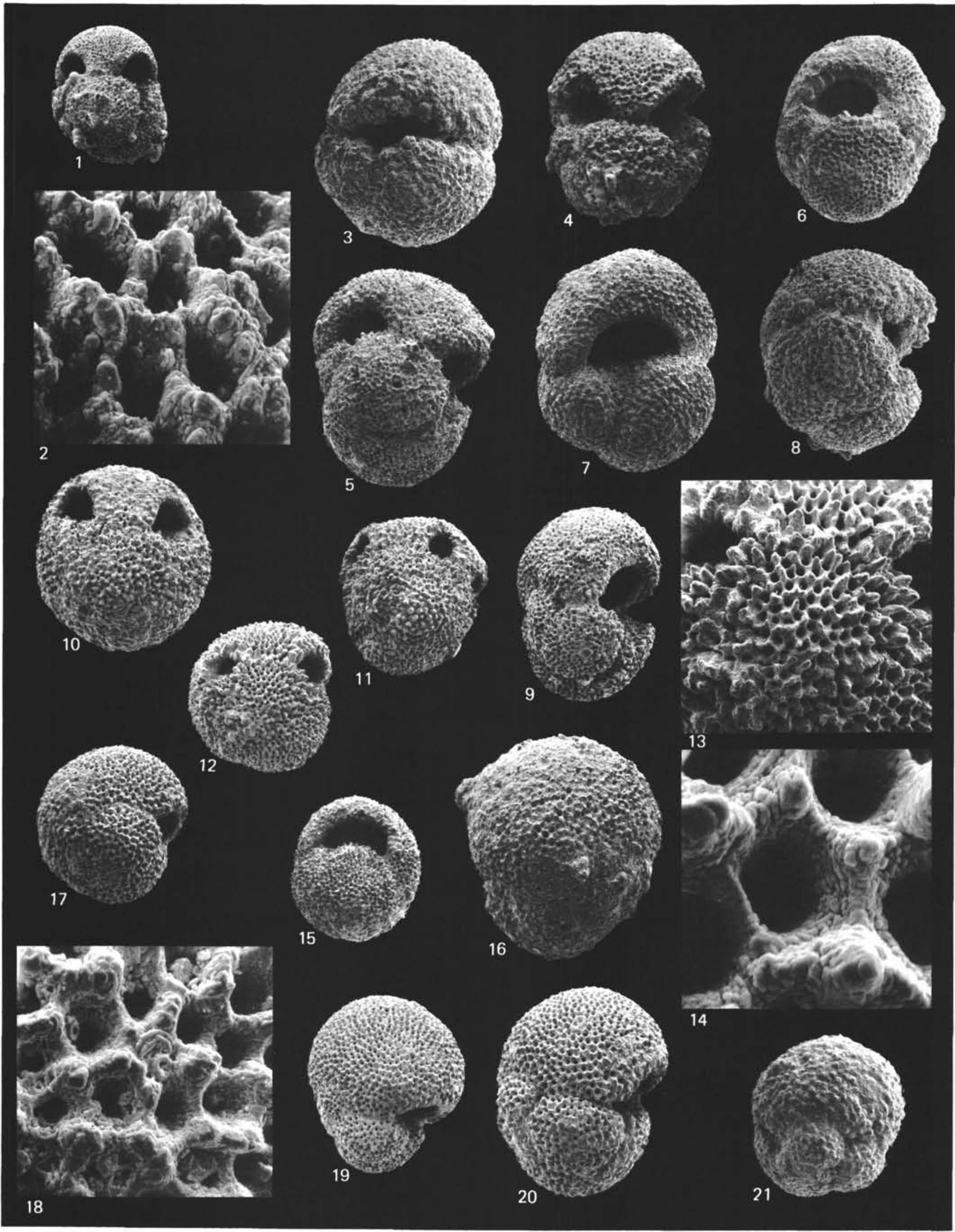




\section{PLATE 6}

Figures 1-3 Globorotalia cerroazulensis frontosa (Subbotina).

1. Sample 363-11-4, 58-60 cm.

2, 3. Sample $363-11-1,58-60 \mathrm{~cm}$. Globorotalia lehneri to Hantkenina aragonensis Zone: middle Eocene.

1. Spiral view (C-33691), $100 \times$.

2. Side view $(C-33692), 80 \times$.

3. Umbilical view (C-33693), $80 \times$.

Figures 4-6 Globorotalia cerroazulensis possagnoensis Toumarkine and Bolli. 100×. Sample 363-11-1, $58-60 \mathrm{~cm}$. Globorotalia lehneri to Hantkenina aragonensis Zone: middle Eocene.

4. Spiral view (C-33694).

5. Side view (C-33695).

6. Umbilical view (C-33696)

Figures 7-9 Globorotalia cerroazulensis pomeroli Toumarkine and Bolli. 100X.

7, 8. Sample 363-10, CC. Orbulinoides beckmanni Zone: middle Eocene.

9. Sample 363-9, CC. Globigerinatheka semiinvoluta Zone. upper Eocene.

7. Spiral view (C-33697)

8. Side view (C-33698).

9. Umbilical view (C-33699).

Figures 10-12 Globorotalia cerroazulensis cerroazulensis (Cole). Sample 363-10-4, 58-60 cm. Truncorotaloides rohri Zone: middle Eocene.

10. Spiral view (C-33700), 100X.

11. Side view (C-33701), 100X.

12. Umbilical view (C-33702), 80X.

Figures 13-15 Globorotalia cerroazulensis cocoaensis Cushman. $100 \times$. Sample 363-9, CC. Globigerinatheka semiinvoluta Zone: upper Eocene.

13. Spiral view (C-33703).

14. Side view (C-33704).

15. Umbilical view (C-33705).

Figures 16,17 Details of Fig. 7. These figures show the dissolution effects on the external layers which more or less disappear.

16. The initial spire become clearly visible as a result of decalcification, $500 \times$.

17. External wall layers with large pores above and the inner, finer perforated wall layer below, $250 \times$.

Figure 18 Detail of Fig. 11. 500×. Part of the outer layers remain into the depressed sutures.

Figure 19 Detail of Fig. 12. $500 \times$. id. to Fig. 18. 


\section{PLATE 6}
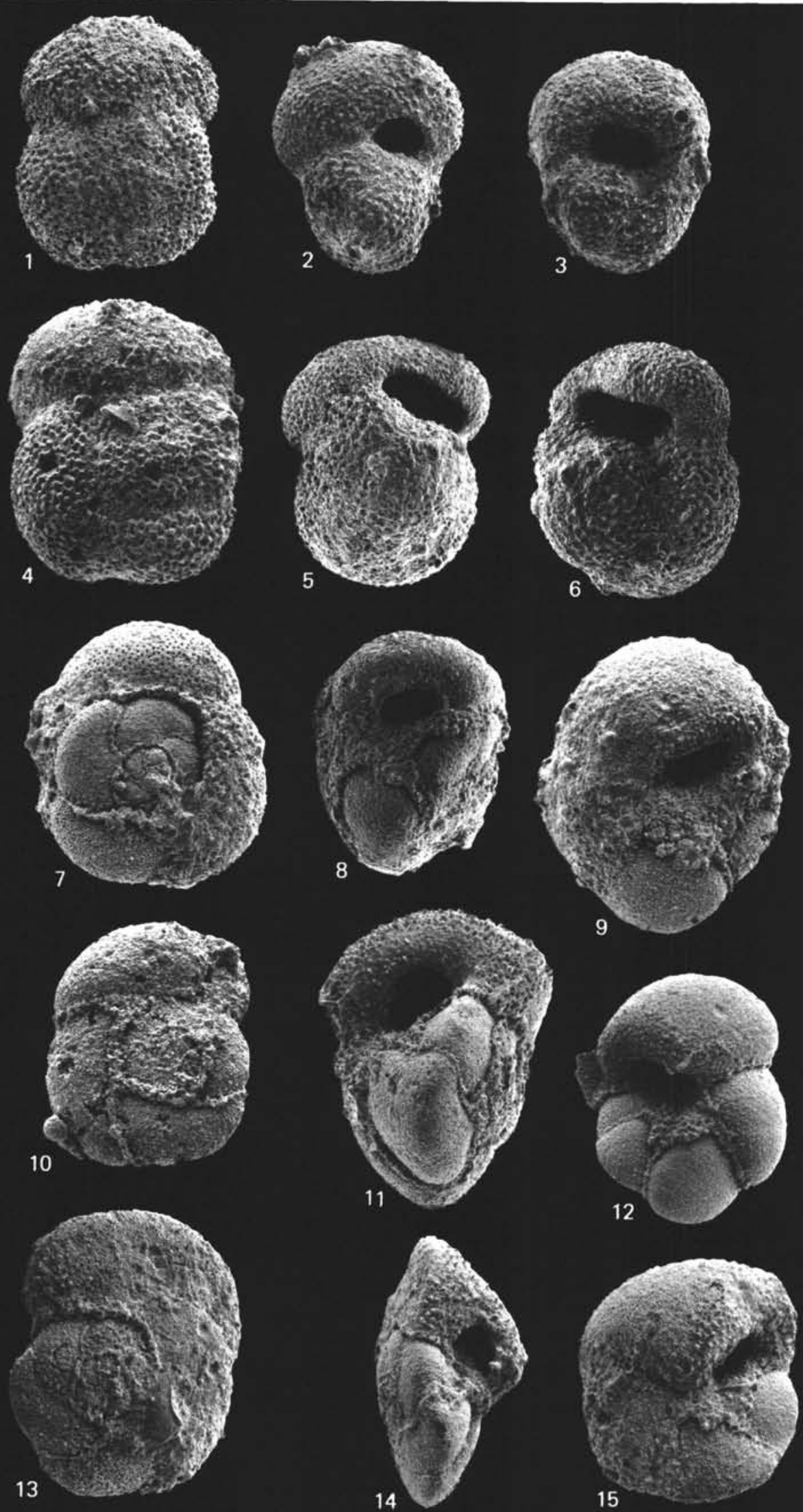

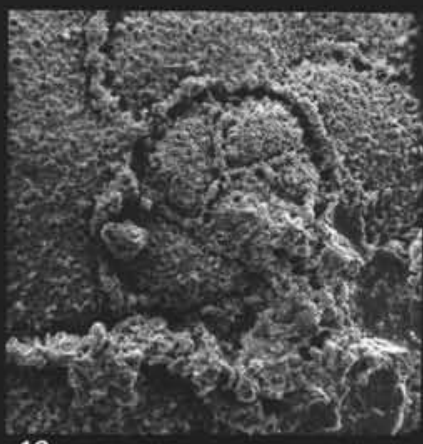

16

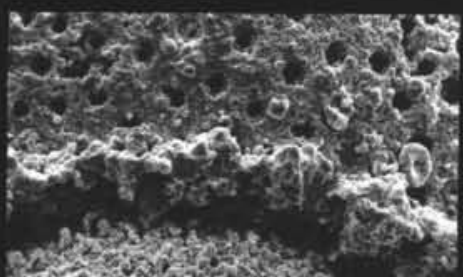

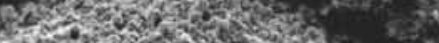

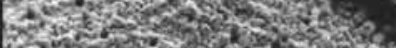

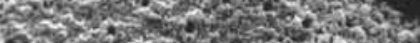
Q.7.

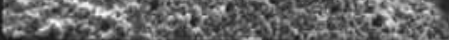
17

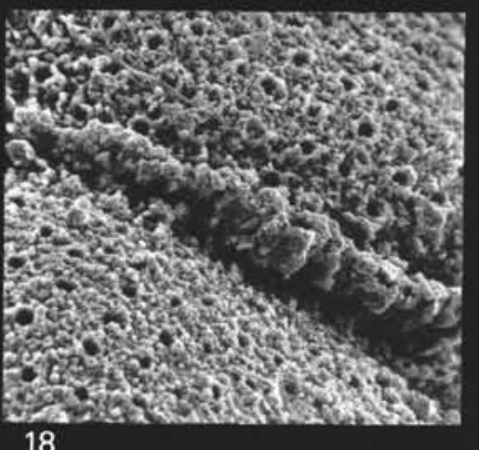

Aly

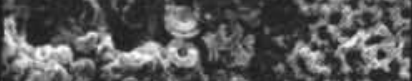

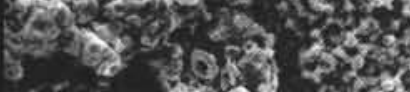
2. 12 \&3: - 350 .

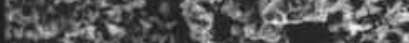

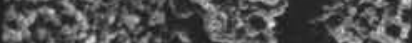

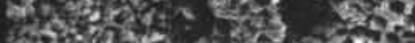

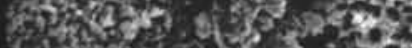

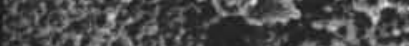

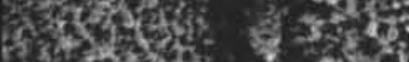

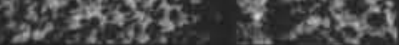
19 


\section{PLATE 7}

Figures 1-12 Globorotalia cerroazulensis cunialensis Toumarkine and Bolli. Fig. 1, 6, 7, 10, 11: 100x. Fig. 3:80×. Fig. 2, 4, 8: $500 \times$. Fig. 5, 9, 12: 1000×. 1, 6, 7, 10. Sample 363-9, CC. Globigerinatheka semiinvoluta Zone: upper Eocene.

3. Sample 363-9-3, 105-107 cm. Globorotalia cerroazulensis s.1. Zone: upper Eocene.

1. Spiral view (C-33706).

2. Detail of Fig. 1.

3. Spiral view (C-33707).

4, 5. Details of Fig. 3.

6. Spiral view (C-33708). Specimen with large ultimate chamber.

7. Side view (C-33709).

8, 9. Details of Fig. 7.

10. Umbilical view (C-33710).

11. Umbilical view (C-33711).

12. Detail of Fig. 11. All figures show that the acute margin is a very thin keel.

Figures 13-18 Globorotaloides carcoselleensis Toumarkine and Bolli. Fig. 13, 14, 15, 18: 100×. Fig. 16, 17: 500×. Sample 363-10, CC. Orbulinoides beckmanni Zone: middle Eocene.

13. Spiral view (C-33712).

14. Side view (C-33713).

15. Umbilical view (C-33714).

16. Detail of Fig. 15. Final coarsely perforated chamber, bordered by a non-perforated lip covering the umbilical area.

17. Umbilical view (C-33715).

18. Detail of Fig. 17. id to Fig. 16. 


\section{PLATE 7}

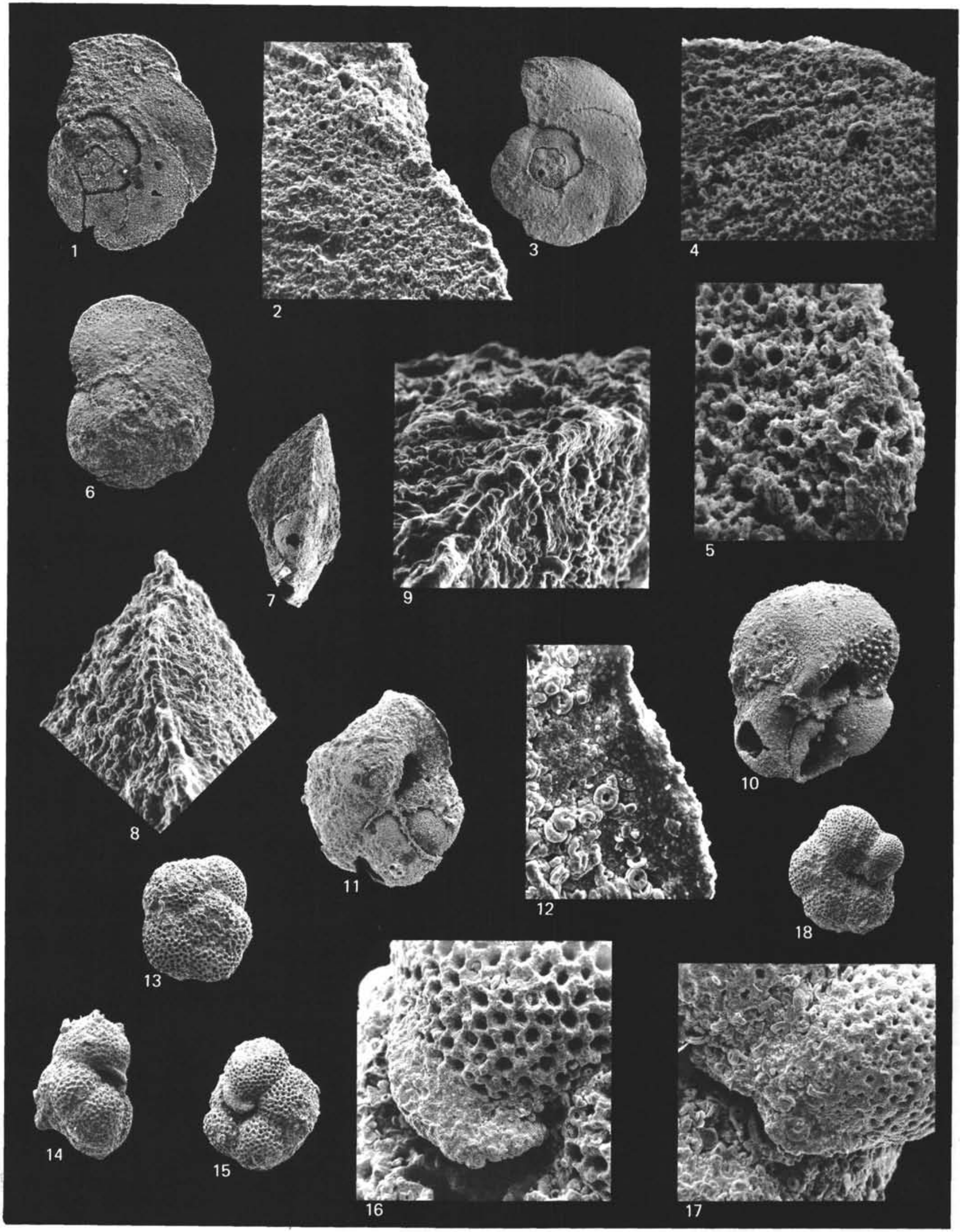




\section{PLATE 8}

Figures 1, 2 Globorotalia gemma Jenkins. 150×. Sample 360-34-3, 89-91 cm. Globigerina ampliapertura to Cassigerinella chipolensis/Pseudohastigerina micra Zone: middle to lower Oligocene.

1. Umbilical view (C-33716).

2. Spiral View (C-33717).

Figures 3, 4 Globorotalia opima nana Bolli. 100×. Sample 360-30-3, $92-94 \mathrm{~cm}$. Globorotalia opima opima Zone: middle Oligocene.

3. Oblique umbilical view (C-33718).

4. Side view (C-33719).

Figures 5,6 Globorotalia pseudocontinuosa Jenkins. 100×. Sample 360-29-2, 73-75 cm. Globorotalia opima opima Zone: middle Oligocene.

5. Side view (C-33720).

6. Oblique umbilical view (C-33721).

Figures 7, 8 Globorotalia opima opima Bolli. 100×. Sample 360-30-3, $92-94 \mathrm{~cm}$. Globorotalia opima opima Zone: middle Oligocene.

7. Oblique umbilical view (C-33722).

8. Side view (C-33723).

Figure 9 Globigerina labiacrassata Jenkins. $80 \times$. Sample 360-29-2, 73-75 cm. Globorotalia opima opima Zone: middle Oligocene. Umbilical view. Very large, rimmed aperture (C-33724).

Figures 10,11 Globigerina ciperoensis ciperoensis Bolli. 100×. Sample 363-3-1, 58-60 cm. Globigerina ciperoensis ciperoensis Zone: upper Oligocene.

10. Spiral view (C-33725).

11. Umbilical view (C-33726).

Figures 12-16 Globigerina ciperoensis angulisuturalis Bolli. Fig. 12, 15: 100×. Fig. 13, 16: $250 \times$. Fig. 14: $500 \times$. Sample 363-3-1, 58-60 cm. Globigerina ciperoensis ciperoensis Zone: upper Oligocene.

12. Spiral view (C-33727). U-shaped sutural depressions.

13, 14. Details of Fig. 12. Strongly depressed sutures, large sized pores on upper part of chamber smaller sized ones in sutural depressions. The small white points in the sutural depression are the initial shapes of recrystallization.

15. Umbilical view (C-33728). U-shaped deep sutures. Large umbilicus. The last chamber has a thinner wall and finer perforation than the preceding ones.

16. Detail of Fig. 15.

Figure 17 Globigerina angiporoides Hornibrook. 80×. Sample 360-32-1, 107-110 cm. Globigerina ampliapertura to Cassigerinella chipolensis/Pseudohastigerina micra Zone: middle to lower Oligocene. Umbilical view (C-33729).

Figures 18, 19 Globorotaloides testarugosa (Jenkins) Sample 360-28-1, 87-89 cm. Globorotalia opima opima Zone: middle Oligocene.

18. Umbilical view (C-33730), $80 \times$.

19. Detail of Fig. 18. Coarsely granulated wall structure, $250 \times$.

Figures 20, 21 Globigerina decoraperta Takayanagi and Saito. Sample 363-1-1 (top). Globorotalia menardii Zone: middle Miocene.

20. Umbilical view (C-33731). Very large aperture, bordered by a thick rim, $80 \times$.

21. Detail of Fig. 20. Extremely large pores, 1000×.

Figures 22, 23 Globoquadrina globularis Bermudez. Sample 360-27-1, 58-60 cm. Globigerina ciperoensis ciperoensis Zone: upper Oligocene.

22. Umbilical view (C-33732), 50X.

23. Detail of Fig. 22. Teeth visible inside the umbilicus, 150X. 
PLATE 8

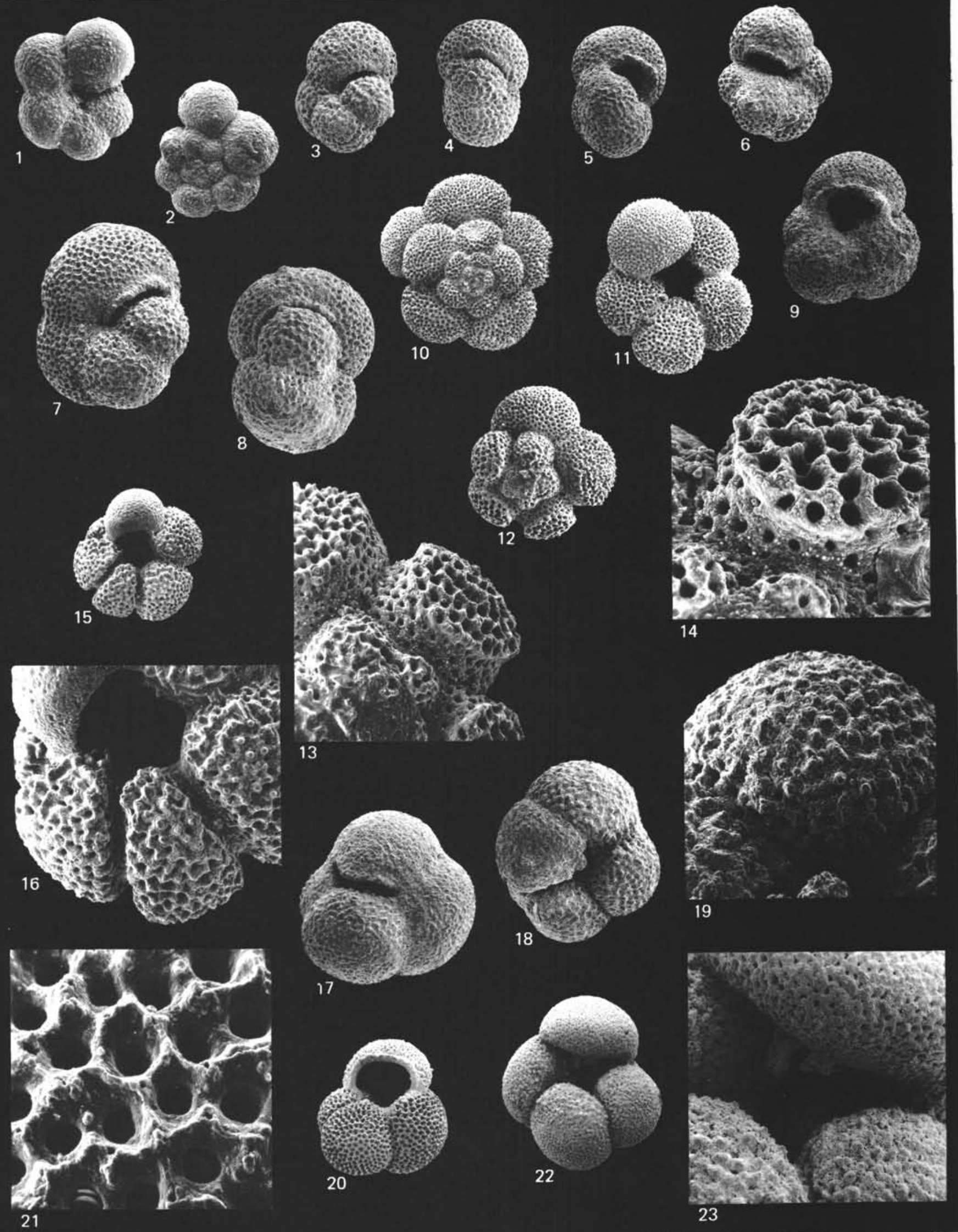




\section{PLATE 9}

Figures 1-8 Globigerina binaiensis Koch. Fig. 1, 2: 75×. Fig. 3, 4: $500 \times$. Fig. 5, 7:100×. Fig. 6: 1000×. Fig. 8: $80 \times$.

1, 7. Sample $363-2-5,58-60 \mathrm{~cm}$. Globorotalia kugleri Zone: upper Oligocene.

2. Sample 363-1, CC. Globigerinoides primordius Zone: lower Miocene.

5. Sample 363-2, CC. 8. Sample 360-27-1, 58-60 $\mathrm{cm}$. Globigerina ciperoensis ciperoensis Zone: middle Oligocene.

1. Spiral view (C-33733). Large ultimate chamber.

2. Umbilical view (C-33734). Very flat apertural face.

3, 4. Details of Fig. 2.

5. Side view (C-33735). Inflated spiral face and flat apertural face.

6. Details of Fig. 5.

7. Side view (C-33736).

8. Umbilical view (C-33737).

Figures 9, 10 Globorotalia miozea miozea Finlay $80 \times$.

9. Sample 363-1-4, 75-77 cm. 10. Sample 363-12, $58-60 \mathrm{~cm}$. Globorotalia fohsi lobata Zone: middle Miocene.

9. Spiral view (C-33738).

10. Umbilical view (C-33739).

Figures 11-22 Sample 363-1-4, 75-77 cm. Globorotalia fohsi lobata Zone: middle Miocene.

11-12. Globorotalia fohsi peripheroronda Blow and Banner 100X.

11. Spiral view (C-33740).

12. Umbilical view (C-33641).

13-16. Globorotalia fohsi fohsi Cushman and Ellisor.

13. Umbilical view (C-33742), 100×.

14. Detail of Fig. 13, 500 $\times$.

15. Spiral view (C-33743), $100 \times$.

16. Detail of Fig. 15, 2500x.

17. Transitional form between Globorotalia fohsi fohsi Cushman and Ellisor and Globorotalia fohsi lobata Bermudez. 100×. Spiral view (C33744). The periphery becomes lobate.

18-22. Globorotalia fohsi lobata Bermudez.

18. Spiral view (C-33745). Lobate periphery, $150 \times$.

19, 20. Details of Fig. 18, 500 $\times$ and $100 \times$.

21. Umbilical view (C-33746), 50X.

22. Detail of Fig. $21,500 \times$. 


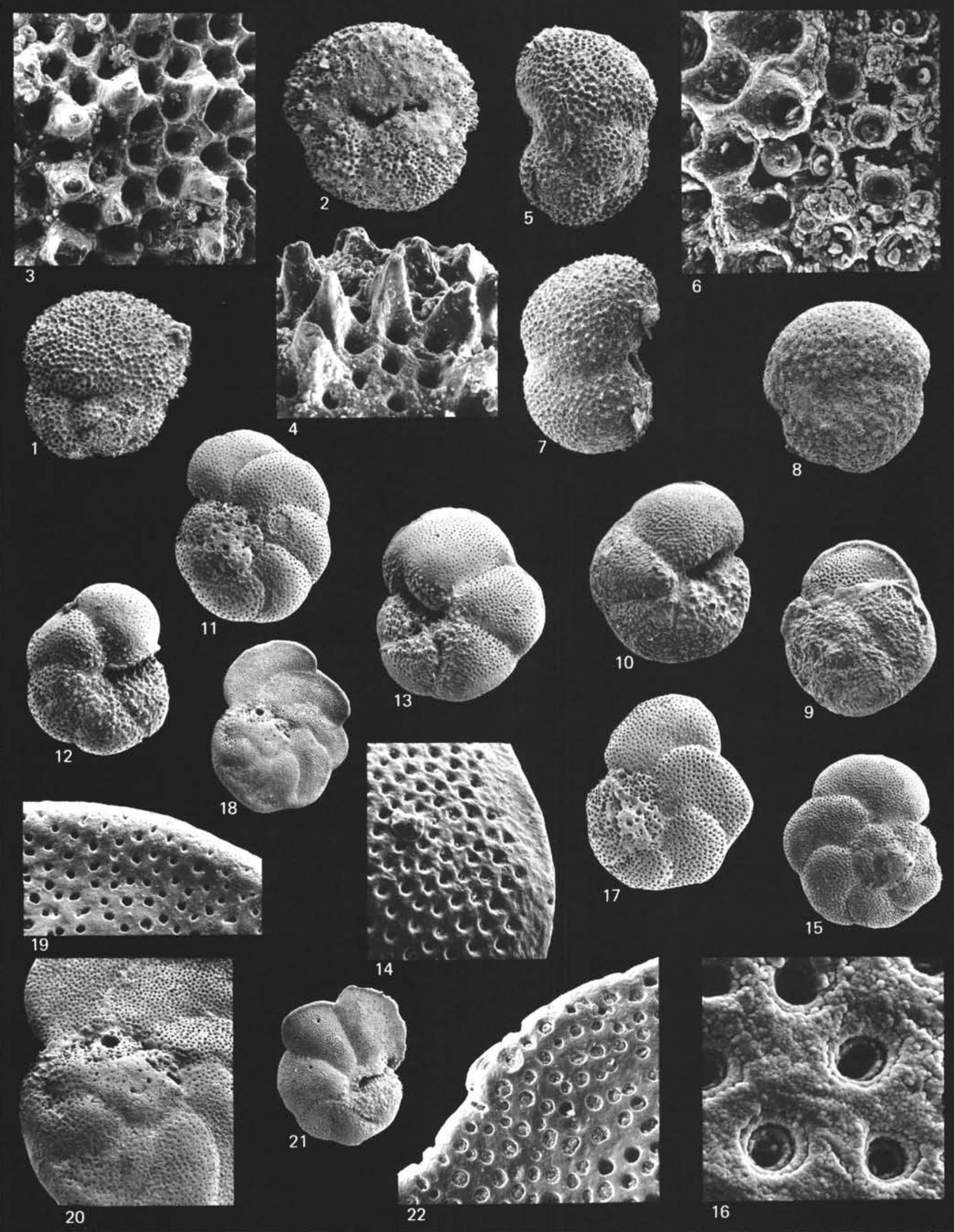




\section{PLATE 10}

Some stages of dissolution on tests of different species.

Figures 1, 2 Globorotalia angulata (White). Sample 364-10-4, $58-62 \mathrm{~cm}$. Globorotalia angulata Zone: middle Paleocene.

1. Spiral view (C-33747), 100X.

2. Detail of Fig. 1, 1000 $\times$.

Figures 3,4 Transitional form between Globorotalia pseudobulloides (Plummer) and Globorotalia trinidadensis Bolli, 100×. Sample 364-10, CC. Globorotalia trinidadensis Zone: lower Paleocene.

3. Umbilical view (C-33748).

4. Spiral view (C-33749). Holes appear in the test wall which is partly decalcified.

Figure 5 Globigerina angiporoides Hornibrook. 100 . Sample $362 \mathrm{~A}-4-3,73-75 \mathrm{~cm}$. Globigerina ampliapertura Zone, middle Oligocene. Umbilical view (C-33750).

Figure 6 Globigerina linaperta Finlay. 100×. Sample 36036, CC. Globorotalia cerroazulensis s.l. to Globigerinatheka semiinvoluta Zone, upper Eocene. Spiral view (C-33751).

Figures 7-9 Globigerina primitiva Finlay. Sample 360-48, CC. Globorotalia lehneri to Hantkenina aragonensis Zone, middle Eocene.

7. Umbilical view (C-33752), $100 \times$.

8. Detail of Fig. 7, $500 \times$.

9. Umbilical view (C-33753). Dissolution of the inner whorls, glittering appearance of test, $100 \times$.

Figures 10-14 Globigerina senni (Beckmann). Sample 364-8-4, 58$60 \mathrm{~cm}$. Globorotalia palmerae to Globorotalia aragonensis Zone: lower Eocene. Empty tests as a result of dissolution of the inner whorls.

10. Umbilical view (C-33754), 100X.

11. Umbilical view (C-33755), 100X.

12. Umbilical view (C-33756), $100 \times$.

13, 14. Details of Fig. 12. Recrystallization of wall crystals, $500 \times$.

Figure $15 \quad$ Globorotalia opima nana Bolli. 100×. Sample 36030-3, 92-94 cm. Globorotalia opima opima Zone: middle Oligocene. Umbilical view (C-33757).

Figures 16-20 Globigerinoides primordius Blow and Banner. Fig. 16: 100×. Fig. 17, 19: 1000×. Fig. 18, 20: 2500×. Sample 363-2-5, 58-60 cm. Globorotalia kugleri Zone: upper Oligocene.

16. Spiral view (C-33758). Decalcification of some parts of the outer layers.

17-20. Details of Fig. 16. Different aspects of dissolution effects on wall surfaces.

17, 18. View of a strongly damaged part.

19, 20. View of a better preserved part. 

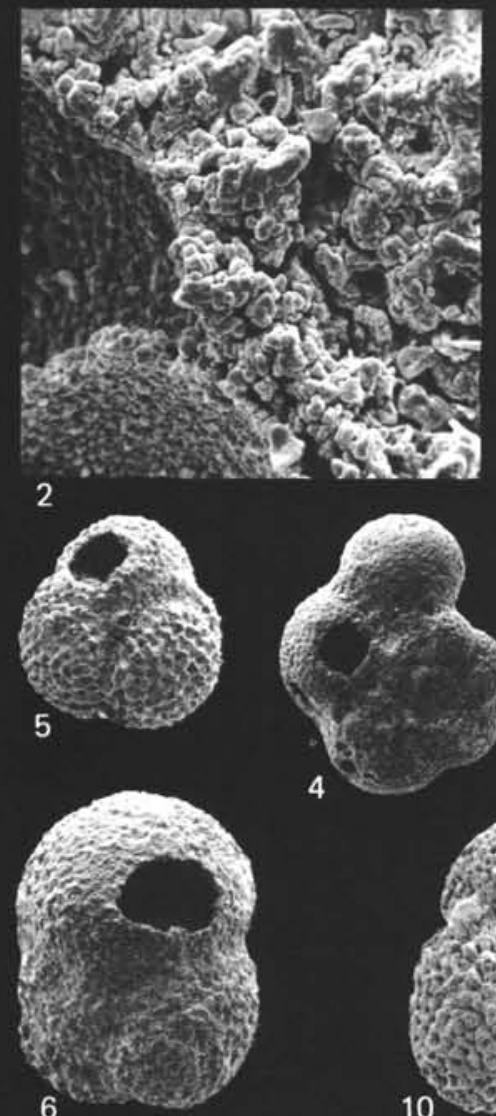

4
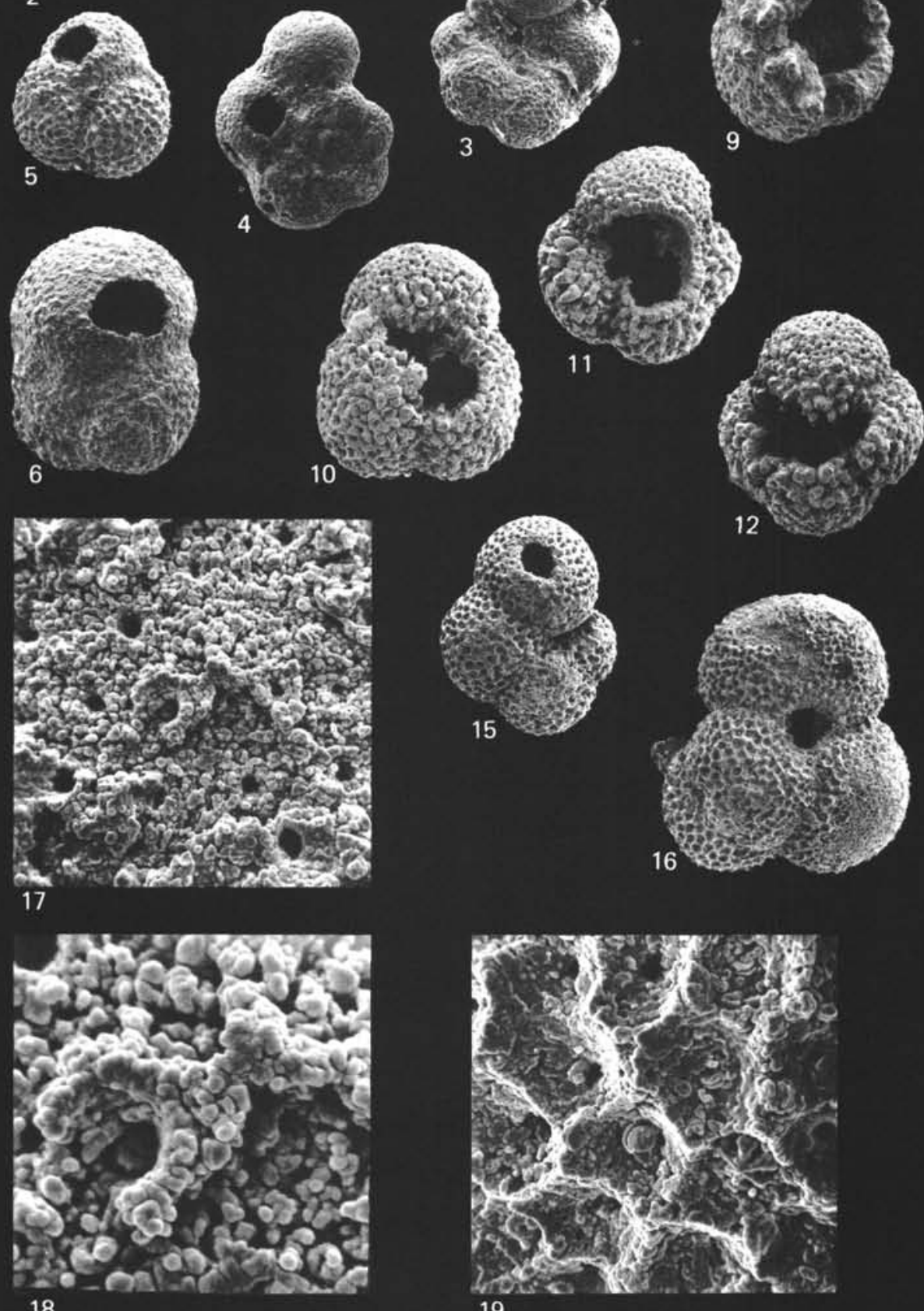

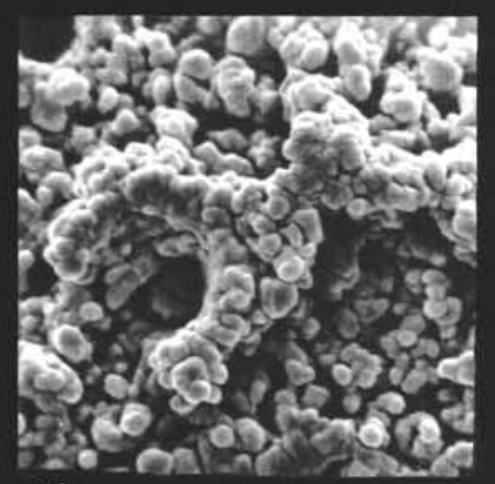

18

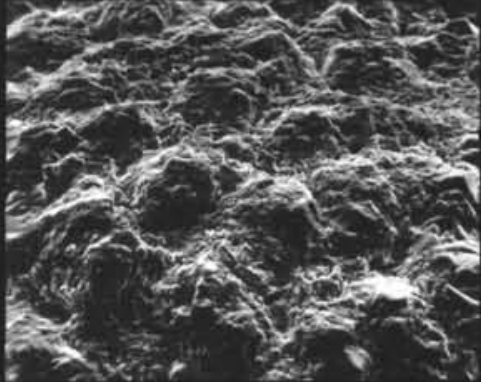

8
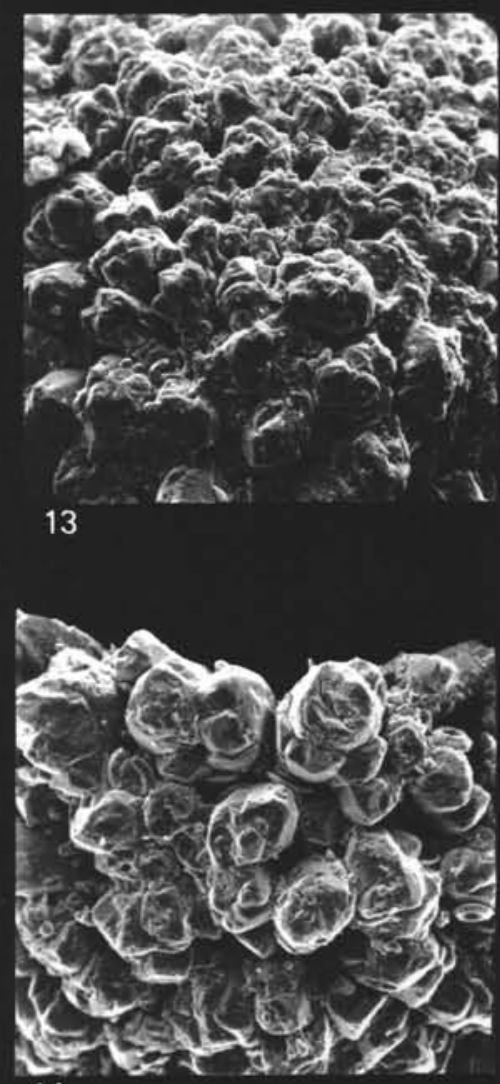

14

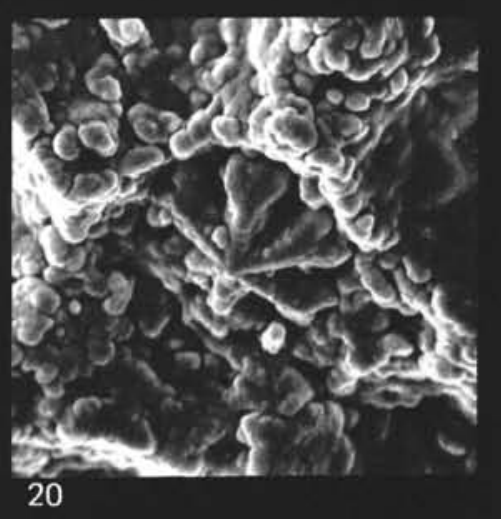




\section{PLATE 11}

Dissolution effects.

All Figures Sample 363-5, CC. Globigerina ampliapertura Zone: middle Oligocene.

Figure 1 Globigerina venezuelana Hedberg. $100 \times$. The last chamber, more corroded, shows hole (C-33759).

Figures 2-4 Globigerina praesaepis Blow.

2. Umbilical view (C-33760), $80 \times$.

3. Spiral view (C-33761), 80X.

4. Detail of Fig. 3 showing the difference of the dissolution between the pores crystals and the others. The specimen appears covered by funnel-shape pustules, $1000 \times$.

Figures 5-11 Globorotalia increbescens (Bandy).

5. Umbilical view (C-33762), 100X.

6. Detail of Fig. 5; well preserved part, $1500 \times$.

7. Spiral view (C-33763), 100×.

8. Detail of Fig. $7,250 \times$.

9, 11. Details of Fig. 8. Last chamber corroded by dissolution, $1000 \times$ and $2500 \times$.

10. Detail of Fig. 8, penultimate chamber, better preserved, $1500 \times$.

Figures 12-17 Globigerina ampliapertura Bolli.

12. Umbilical view (C-33764), $80 \times$.

13. Detail of Fig. 12, $500 \times$.

14. Umbilical view (C-33765), $100 \times$.

15. Spiral view (C-33766), $80 \times$.

16, 17. Details of Fig. 15. The outer layers of the walls are partly dissolved and holes appear. The crystals between the pores are more easily dissolved than those of the pores themselves (as shown also on Fig. 3 and 4). That results in funnel-shape pustules; 16, 1000×; 17, 4000×. 
PLATE 11

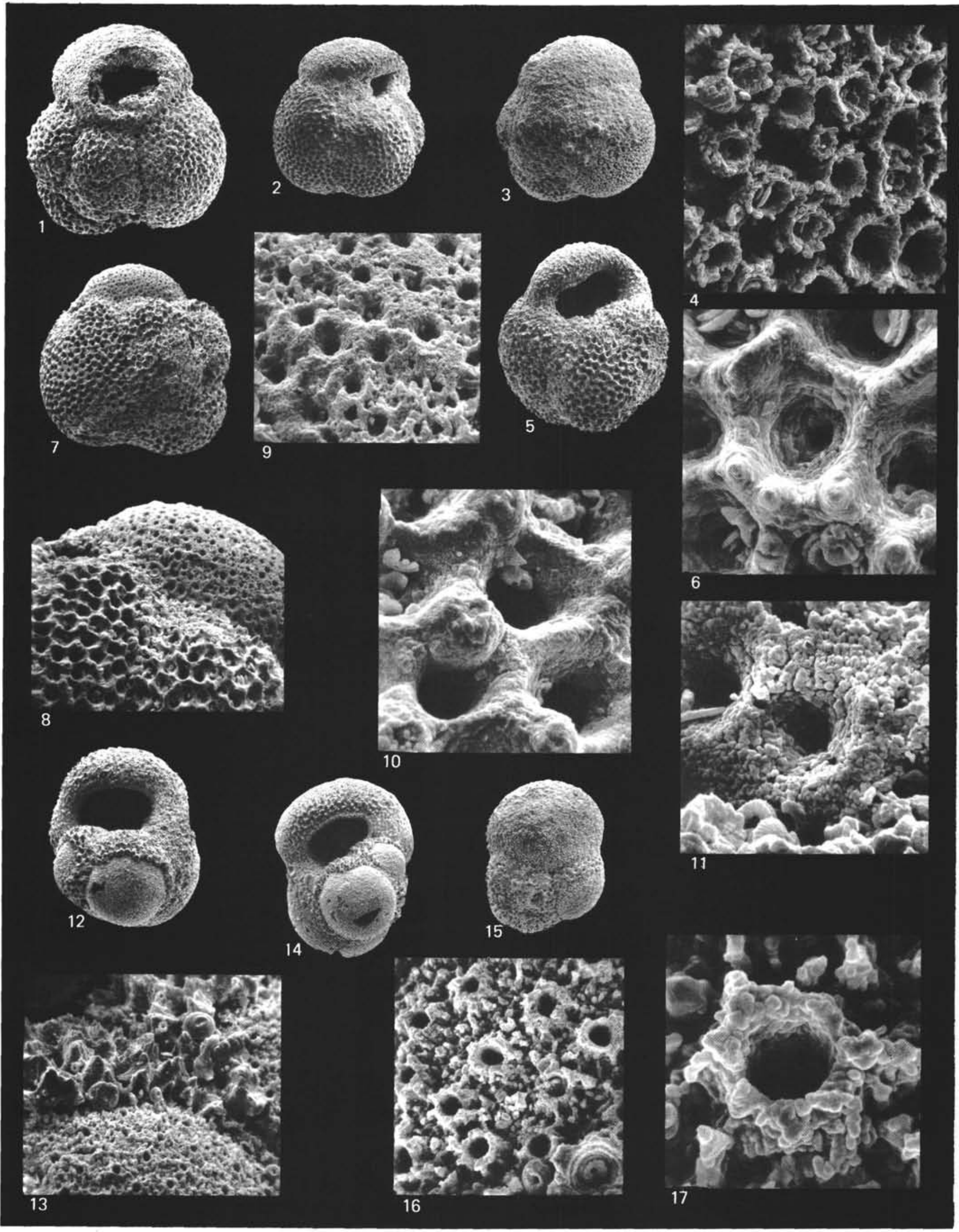

